\title{
A COLONIAL BANK UNDER SPANISH AND AMERICAN SOVEREIGNTY: THE BANCO ESPAÑOL DE PUERTO RICO, 1888-1913
}

\author{
Pablo Martín-Aceña e Inés Roldán de Montaud ${ }^{\propto}$
}

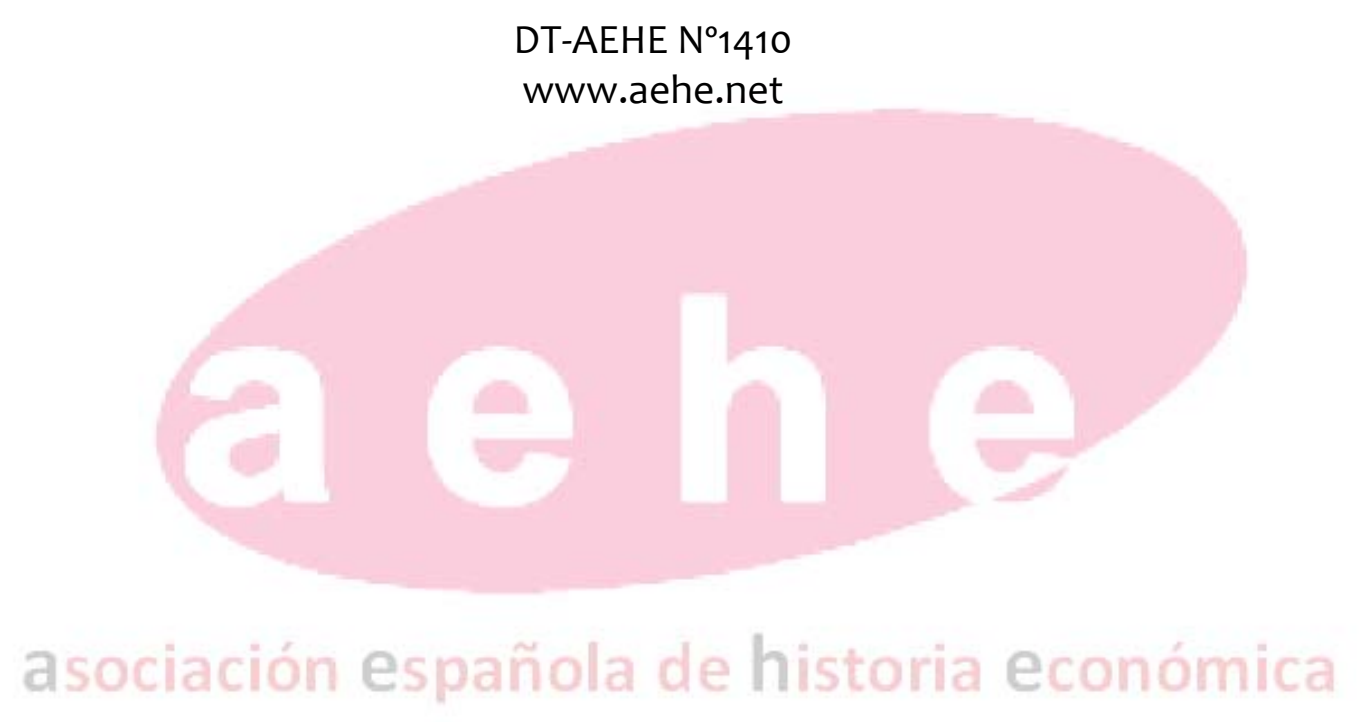

Abril 2014

$\propto(\mathrm{cc}) \mathrm{BY}$-NC-ND This paper is protected by a a Creative Commons licence: AttributionNonCommercial- NonDerivativeWork. The details of the licence can be consulted here: http://creativecommons.org/licenses/by-nc-nd/3.o/deed.en 


\author{
A COLONIAL BANK UNDER SPANISH AND AMERICAN SOVEREIGNTY: THE BANCO \\ ESPAÑOL DE PUERTO RICO, 1888-1913 \\ Pablo Martín-Aceña`e Inés Roldán de Montaud \\ DT-1410, Abril 2014 \\ JEL: G2, N16, N26
}

\title{
RESUMEN
}

En este artículo se estudia la historia del Banco Español de Puerto Rico desde su creación en 1888 hasta su disolución en 1913. El Banco Español fue la única entidad financiera emisora en la isla hasta 1898, año en el que la soberanía sobre Puerto Rico pasó a los Estados Unidos. La creación del Banco estuvo plagada de dificultades y durante su primera década de existencia se encontró con toda clase de obstáculos que entorpecieron su desarrollo. No obstante, el Banco contribuyó a diversificar la estructura financiera de la colonia, a reducir el coste del crédito y a modernizar el sistema monetario de la isla. La transferencia de soberanía fue traumática para la institución: el Banco perdió el monopolio de emisión y tuvo que ajustarse a la legislación financiera de los Estados Unidos. En 1905 adoptó el nombre de Banco de Puerto Rico y se reformaron sus estatutos. El último periodo de su vida fue de notable prosperidad e hizo de nuevo una importante contribución al desarrollo económico de la isla. En conjunto, la historia del Banco es una mezcla de logros y errores, de avances y retrocesos.

Palabras clave: Puerto Rico, bancos, sistema financiero, desarrollo económico, España, Estados Unidos de América.

\section{asociación españ olastract historia económica}

This paper offers the history of the Banco Español de Puerto Rico from its creation in 1888 to its liquidation in 1913. The Banco Español was the sole note-issuing institution of the island until 1898, when Puerto Rico was transferred to the United States. The establishment of the Bank was plagued with difficulties and during its first decade of existence it met with diverse obstacles that hindered its financial development. However, it contributed to diversifying the underdeveloped banking structure of the colony, to bringing down the cost of credit, and to modernizing the island's monetary system. The transfer of sovereignty was traumatic since the Bank lost its issue monopoly and had to adjust to US banking legislation. In 1905, its name was changed to Banco de Puerto Rico and its by-laws were reformed. The last years of the Bank's life were prosperous and it once again made an important contribution to the island's economy. All in all, the history of the institution is a mixture of errors and achievements, a history of setbacks and successes.

Keywords: Puerto Rico, banks, financial system, economic development, Spain, United States of America.

\footnotetext{
- Universidad de Alcalá. Correo electrónico: pablo.martin@uah.es

Consejo Superior de Investigaciones Científicas.
} 


\section{A COLONIAL BANK UNDER SPANISH AND AMERICAN SOVEREIGNTY: THE BANCO ESPAÑOL DE PUERTO RICO,}

$\underline{1888-1913^{\circ}}$

\section{Introduction}

Joseph Schumpeter, Alexander Gerschenkron and Rondo Cameron have argued that to understand economic growth and industrialization we must understand banking ${ }^{1}$. The financial system is critical to the health of the economy because it performs the essential function in an economy of channeling funds from savings to those individuals or firms that have productive investment opportunities. If the financial system does not perform this task well, then the economy cannot operate efficiently and economic growth will be severely hampered. This is also true for Puerto Rico. After several attempts to create a bank of issue, the Spanish government approved the establishment of the Banco Español de Puerto Rico in 1888. The new institution came to enhance the poorly developed financial structure of the colony formed by only a few small saving banks $^{2}$. The other Spanish colony in the area, Cuba, had an issue institution which had been chartered in $1856^{3}$, and even in the Philippines an issue bank had operated since

\footnotetext{
- The authors are grateful to Carlos Marichal, Gail Triner and Eugene White, and also to the participants of the I Congreso Internacional de la Asociación de Historia Económica del Caribe -AHEC-, Santa Marta, Colombia (2-5, November, 2011) for their useful comments. We wish to thank as well the librarians of the Biblioteca de la Universidad de Puerto Rico (Río Piedras) and the archivists of the Archivo General de Puerto Rico. We also thank the referees for their useful comments and observations. The views expressed herein are those of the authors alone. The paper has received financial support from the Spanish Ministry of Science and Innovation. Project ECO2009-08791: Financial crises. Past, present and future. Spain and the International economy. What have we learned? and Project HAR2009-07103: Spanish Biographical Dictionary of Overseas Ministries.

${ }^{1}$ Joseph A. Schumpeter, The theory of economic development (Cambridge, 1934), pp. 95-127; Alexander Gerschenkron, Economic development in historical perspective (Cambridge, 1962), pp. 1-71 and 119151; Rondo Cameron, Banking in the early stages of industrialization (New York, 1967), pp. 183-239.

${ }^{2}$ The standard study of the banking system of the island in the nineteenth century is Annie Santiago de Curet, Crédito, moneda y bancos en Puerto Rico durante el siglo XIX (Río Piedras, 1989). A recent contribution is Francisco Comín, Ángel Pascual and Inés Roldán de Montaud, Las cajas de ahorros de las provincias de ultramar, 1840-1898: Cuba y Puerto Rico (Madrid, 2010), pp. 225-404. Also useful are Ángel Sanz, Reseña histórica de la banca en Puerto Rico (Santurce, 1969), Gilberto Cabrera, Historia económica del comercio y de la industria de Puerto Rico, (Puerto Rico, 1980), pp. 123-132), and Biagio Di Venuti, Money and banking in Puerto Rico (Río Piedras, 1925), pp. 1-30.

${ }^{3}$ Susan J. Fernández, Encumbered Cuba. Capital markets and revolt, 1878-1895 (Gainesville, 2003), p. 68. The Cuban issuer in Inés Roldán de Montaud, La banca de emisión en Cuba, 1856-1898 (Madrid, 2004).
} 
this latter date ${ }^{4}$. In the adjacent Caribbean colonies, issue banks had been established before mid-nineteenth century ${ }^{5}$. Puerto Rico was therefore and, in fact, an exception ${ }^{6}$.

The failure to establish financial institutions was costly in terms of the social and economic fabric of the island, as the absence of banks hampered the development of the economy. Before emancipation in 1873, landowners found it difficult to purchase sufficient slaves to provide the labor needed to work in the fields and the mills. After emancipation, the lack of banking services slowed industrialization because sugar and coffee growers found it difficult to renovate their machinery or introduce new technology ${ }^{7}$.

The constitution of a note-issuing institution was expected to increase the supply of credit, break the financial power exerted by the merchant class, reduce the cost of capital, and contribute to the diversification of the means of payments, by bringing convertible paper notes into circulation. It was also expected to solve the currency scarcity endured by the colony since the interruption of the "situado" (funds brought from the Mexican Treasury) in $1815^{8}$. This was what Asenjo y Arteaga, a Puerto Rican intellectual and economist, envisioned when in 1862 he proposed the creation of a Banco Español de Puerto Rico as an institution to nurture the hidden wealth of the colony, to mobilize the resources needed by planters and manufacturers, a bank that would contribute toward increasing monetary circulation and which would end the

\footnotetext{
${ }^{4}$ Maria Teresa Colayco, A tradition of leadershipp. Bank of the Philippine Islands (Manila, 1984); Virginia Benítez Licuanan, Money in the Bank. The story of money and banking in the Philippines (Manila, 1985).

${ }_{5}^{5}$ Albert S. J. Baster, Imperial Banks (London, 1929); Pierre Denizet, Les banques coloniales (Paris, 1899); Jaap van Soest, Trustee of the Netherland Antilles. A history of money, banking and the economy with special reference to the central Bank van de Netherlanse Antillen, 1828-6 february-1978 (Zutphen, 1979-1980). Excellent chapters with the history of issue banks in Latin America in Pedro Tedde and Carlos Marichal (coords.), La formación de los bancos centrales en España y América Latina, siglos XIX y XX (Madrid, 1994).

${ }^{6}$ The lack of modern financial institutions in Adam Szaszdi, "Credit without banking in early nineteenth century Puerto Rico", The Americas, 19, 2, (1962), pp. 149-171; Laird W. Bergard, Coffee and Growth of Agrarian Capitalism in Nineteenth Century Puerto Rico (Princeton, 1983), pp. 152, 168 and 213; Andrés Sánchez Tarniella, La economía de Puerto Rico (Bayoán, 1976), p. 62; Francisco A. Scarano, Sugar and slavery in Puerto Rico. The plantation economy of Ponce, 1800-1850 (Maddison, 1984), pp. 144-159; Guillermo Baralt, Tradición de futuro: el primer siglo del Banco Popular de Puerto Rico, 1893-1993 (San Juan, 1993), pp. 10-13, and Jorge L. Chinea, "Confronting the crisis of the slave-based plantation system in Puerto Rico: bureaucratic proposal for the agricultural modernization, diversification and free labour, c. 1846-1852", Journal of Latin American Studies (2010), 42, pp. 121-154. Also the references in note 2 .

${ }^{7}$ James L. Dietz, Economic History of Puerto Rico: Institutional Change and Capitalist Development, (Princeton, 1986), pp. 25-30.

${ }^{8}$ Carlos Marichal and Matilde Souto, "Silver and situados: New Spain and the Financing of the Spanish Empire in the Caribbean in the Eighteenth Century", The Hispanic American Historical Review, 74, 4, (1994), pp. 587-613.
} 
financial dependency on the Dutch island of St. Thomas ${ }^{9}$. Baldiority de Castro, the leader of the Autonomist Party, also believed that with a bank the economy of the island would prosper; without one, its commerce would remain stagnant ${ }^{10}$. On the other hand, for the institution, the issue of banknotes would be an important source of profits, particularly if the issue was enjoyed in exclusivity. The banknotes, a short-term liability without hardly any cost except that of the printed paper, complemented the company's own resources (paid-up capital plus reserves) enhancing its capacity to grant loans and credits, or to buy bonds and stocks, the basic earning assets of any financial firm.

In 1877, a joint-stock banking firm was chartered, the Crédito Mercantil, which after ten years gave way to the Banco Español de Puerto Rico, the first and sole issue institution on the island until 1898. When sovereignty was transferred to the United States, the Bank (soon renamed Banco de Puerto Rico) survived until the expiry of its charter in 1913, but it no longer enjoyed the monopoly of issue. Although the performance of the Bank fell short of the expectations raised when it was created, all in all it contributed to diversifying the colony's financial and monetary structure, broke the credit oligopoly exerted by the (Spanish) merchant bankers and forced down interest rates from their traditionally rampant levels. Moreover, it was an excellent business for its shareholders, who obtained handsome profits.

This article reviews the twenty five year long history of the Bank, from its inception to its liquidation. Studying an institution such as the Banco Español de Puerto Rico is important for both historical and political reasons. First, the Bank is an excellent viewpoint from which to observe the evolution of the Puerto Rican economy. Second, learning the history of the Bank will increase our knowledge of Puerto Rican financial development under Spanish and later US sovereignty, and will add to our understanding of colonial banking in the Caribbean area. Finally, the story of the Banco Español de Puerto Rico, the most important financial institution on the island before 1913, has never before been told ${ }^{11}$.

\footnotetext{
${ }^{9}$ Federico Asenjo y Arteaga, El comercio de la Isla y la influencia que en él ha de ejercer el Banco Español de Puerto Rico (Puerto Rico, 1862).

${ }^{10}$ Román Baldiority de Castro, Bases para la fundación de un banco de emisión y descuento (Puerto Rico, 1871).

${ }^{11}$ So far, the Banco Español de Puerto Rico archives have not been found. In his Informe relativo al Banco Español de Puerto Rico luego Banco de Puerto Rico (San Juan, 1925), Manuel Paniagua, the last president, mentions the existence of two books containing the minutes of the sessions of the General Meeting of Shareholders, fifteen containing the minutes of the Governing Council and eleven for the Executive Committee, in addition to several accounting, auxiliary and correspondence books. In the absence of this internal documentation, the Bank's history must be reconstructed using the information provided in its annual reports, and documentation held in the Colección Puertorriqueña (University of
} 
The remainder of the article is structured as follows. The next section focuses on the steps that led to the establishment of the Bank. Section three examines the financial operation of the Bank under Spanish sovereignty, and the following two sections look at the evolution of the Bank under US administration. The paper concludes with a last section that is both speculative and brief.

\section{The constitution of the Banco Español de Puerto Rico}

The promoter of the Banco Español de Puerto Rico was José Ramón Fernández, marquis of La Esperanza, a landowner and former trader on the island. In 1875, he conceived the idea of establishing an issuing institution with the indemnity that the decree of March 23, 1873 abolishing slavery conceded to the owners of the 29,229 slaves who were given their freedom. Compensation was set at seven million pesos, to be paid out of the proceeds of a loan. However, the operation failed and hence the government decided to distribute 70,000 securities or bonds (worth 100 nominal pesos each) among the former slave-owners. The bonds carried a 6 per cent annual interest and they were expected to be paid-back in sixteen years. Nevertheless, the bondholders found difficulties in the collection of the annual interest due to the budgetary deficits of the Puerto Rican Treasury. As a consequence, the paper had depreciated and this made attractive for some of the bondholders to exchange their titles for shares of the Crédito Mercantil ${ }^{12}$.

In October 1875, those bondholders interested in the future bank were convened, and after several meetings the statutes were approved ${ }^{13}$. However, the plans of the marquis de La Esperanza and his partners met with a series of obstacles. One of these

Puerto Rico-Río Piedras), in the Archivo General de Puerto Rico and in the Archivo Histórico Nacional (Madrid). Sources in the National Archives and Record Administration have also been checked. Despite the fact that the Bank's books are still missing we believe that the primary information collected for this paper allows to provide an accurate story of the institution.

12 Compensation in Cayetano Coll y Toste, Boletín Histórico de Puerto Rico (BHPR) (San Juan, 19141927), vol. II, t. IV, p. 95; Lidio Cruz Monclova, Historia de Puerto Rico (Río Piedras, 1952-1964), vol. II, pp. 268-272 and 484-485. For a recent study, see Inés Roldán de Montaud, "Las haciendas públicas de Cuba y Puerto Rico desde el grito de la independencia hasta el final de la colonia", in Inés Roldán de Montaud (ed.), Las haciendas públicas en el Caribe hispano durante el siglo XIX (Madrid, 2008). Compensation was also used to found banks in the French and Dutch colonies, Pierre Denizet, Les banques coloniales (Paris, 1899) and Jaap van Soest, Trustee of the Netherlands Antilles: a history of money, banking and the economy, with special reference to the central Bank van de Nederlandse Antillen 1828-6, February-1978 (Zutphen 1979-1980).

13 Archivo Hstórico Nacional (Madrid) (AHN), Ultramar, 321/7, doc. 9, "Proyecto de Estatutos y Reglamentos para el establecimiento de un banco en la isla de Puerto Rico". 
was the strong opposition from well organized groups of merchant bankers and local lenders, many of whom were of Spanish extraction. They had held control of the commercial and financial circuits of the island since the early nineteenth century, if not before, and considered that any project to establish a bank would threaten their position of financial preeminence on the island. They regarded banks as dangerous competitors, and hence they had no incentive whatsoever to be part of any formal financial institution. As the prominent lawyer Joaquín M. Sanromá described so graphically in 1873, "in Puerto Rico it has been impossible to found even the most insignificant credit institution [...] because it has been blocked by certain men of position who called themselves unconditionally Spanish" ${ }^{\prime 14}$. Of similar magnitude was the resistance on the part of the government in Madrid to the constitution of an issuing bank without their prior authorization ${ }^{15}$.

Having seen their initial project frustrated, in 1877 the promoters decided to establish a commercial bank without the power to issue notes and with the name of Crédito Mercantil. Those former slave owners who were interested transferred their bonds to the entity in exchange for shares, thus becoming shareholder-owners of the credit company, which would assume responsibility for collecting the annuities from the Treasury ${ }^{16}$. However, the directors of the Crédito Mercantil persevered in their goal of issuing notes and made several representations to the Spanish Ministry of Overseas Territories (Ministerio de Ultramar), but the reply from Madrid was that in order to create a bank of issue, such as those in the metropolis, Cuba and the Philippines, it would be necessary to apply to the government for specific authorization.

Another decade elapsed before Puerto Rico would have an issuing entity. Seven projects were presented between 1878 and 1887, only to encounter obstacles of all kinds. On the one hand, there was the traditional opposition of the local merchantbankers, and on the other, the firm stance taken by the government in Madrid, which demanded that the issuing company be constituted using local resources unrelated to the indemnity. A further impediment was the fear on the part of the Spanish authorities that

\footnotetext{
14 Joaquín María Sanromá, Puerto Rico y su Hacienda (Madrid, 1873), p. 8. The prominent role of commercial firms and Spanish merchant houses is a common theme in the literature on the economic history of Puerto Rico. See references in notes 2 and 6, and also Ángel G. Quintero Rivas, "Background to the emergence of imperialist capitalism in Puerto Rico", in Adalberto López and Jaime Petra (eds.), Puerto Rico and Puerto Ricans. Studies in history and society (Cambridge Mass., 1974), pp. 87-117, and 218-219); Rafael De Jesús Toro, Historia económica de Puerto Rico (Cincinnati, 1982), p. 59; Dietz, Economic History of Puerto Rico, pp. 29-30; Baralt, Tradición de futuro, p. 13.

${ }^{15}$ Santiago de Curet, Crédito, moneda y bancos, pp. 109-122.

${ }^{16}$ AHN, Ultramar, 321/7.
} 
such an entity might fall into the hands of merchants on the island who sympathized with the independence movement ${ }^{17}$.

Finally, on March 23, 1887, the government authorized the creation of a bank of issue and discount. A tender process was opened, and two proposals were presented: one endorsed by Eulogio Despujols and Francisco Lastre on behalf of the Crédito Mercantil, and another by a group of merchants and bankers on the island, in association with several French financiers ${ }^{18}$. The government granted the concession to the former by Royal Decree of May $5,1888^{19}$. The capital was set at 1.5 million pesos and the term of the concession was 25 years. Thus, unless an extension were to be granted, the entity would be dissolved in 1913. In exchange for the right to issue, the Banco Español de Puerto Rico provided a loan of 500,000 pesos to the island Treasury, and the government reserved the right to appoint the governor ${ }^{20}$. During its twenty five years of existence, the bank was governed by a Board of Directors initially composed of twelve board members, or directors, although this number was reduced to eight in 1905. Until 1898, board membership was restricted to Spanish citizens or naturalized foreigners resident in the island's capital. When the Bank was constituted, the number of shareholders totaled 344 , of whom the majority (183) were resident in the capital, and the official headquarters of the Bank were established in San Juan Bautista de Puerto Rico $^{21}$.

However, the Bank was not established until early $1890 .^{22}$ Two obstacles hindered its beginning. On the one hand, the government stipulated that the concession be granted to the signatories of the application, but not in their roles as representatives of the Crédito Mercantil. This obliged the latter to raise capital independent of that committed to the Mercantil. Lacking the funds, they were forced to dissolve the company. The second stumbling block was the requirement that the capital had to be paid-up in national or Spanish silver currency, rather than in the Mexican silver pesos,

\footnotetext{
${ }^{17}$ Santiago de Curet, Crédito, moneda y bancos, pp. 110-22. Sánchez Tarniella, La economía de Puerto Rico, p. 62. Applications of June 20 and December 7, 1886, in AHN, Ultramar, 332/6, no. 4, fols. 1-7, and no. $328 / 12$. no. $1-4$.

${ }^{18}$ The proposal was signed by Leoncio Bloch, managing director of the Banque Trasatlantique, and Joseph T. Silva, a businessman from Puerto Rico. Details in the Royal Decree of May 5, 1888. Informe relativo al Banco Español, p. 10, and Santiago de Curet, Crédito, moneda y bancos, pp. 156-164.

${ }^{19}$ The Statutes were approved by the decree of May 5, 1888. The Bylaws were approved by royal order of November 22, 1892, Banco Español de Puerto Rico (BEPR), Memoria anual, (1893), p. 11.

${ }^{20}$ The concession to the Banco Español de Puerto Rico followed the precedent set when the monopoly of issue to the Bank of Spain was granted in 1874, Rafael Anes Alvarez, "El Banco de España (1874-1914): un banco nacional”, in La banca española en la Restauración (Madrid, 1974), vol. I, pp. 107-215.

${ }^{21}$ BEPR, Estatutos (Puerto Rico, 1888), article 2; BEPR, Memoria (1891), p. 9.

${ }^{22}$ Boletín Mercantil, February 2, 1890.
} 
which was the money most widely used on the island. Although the concession holders asked to be allowed to raise the capital in Mexican currency, this request was opposed by the Ministry of Overseas Territories, which intended to address the pending monetary duality of the colony in the near future ${ }^{23}$. This obstacle prevented the concession holders from paying up the total amount of authorized capital, 1.5 million pesos, and payment was limited to only $375,000 \operatorname{pesos}^{24}$.

\section{The Bank under Spanish sovereignty, 1890-1898}

The Banco Español opened its doors on February 1, 1890, ${ }^{25}$ and its operations ran smoothly throughout its first year. However, the directors highlighted an initial difficulty, which was the same one that afflicted the island's economy as a whole: the monetary duality. In other words, the existence of two currencies in circulation: the Mexican peso and the "national" or Spanish peso. These were both silver coins with only minor differences in weight and fineness. At the beginning of the decade, the exchange rate between them was almost at par or with a small 5 per cent discount for the Mexican currency. Over and above the nuisance of double accounting according to whether transactions were carried out in one currency or the other, the problem really lay in the fact that it was the Mexican currency which was mainly in circulation, whereas the Banco Español had to pay up its capital in "national" money. But above all it would be obliged to issue its notes also in "national currency, the one that the public used least. The Bank's directors were convinced that this would limit the development of the institution ${ }^{26}$.

Despite these fears, economic performance in the first year was promising. This was acknowledged by the governor before the shareholders' meeting when he stated: "The first financial year has been gratifying (and) has permitted the distribution of a dividend which undoubtedly exceeds the expectations of most of the shareholders" 27. The following two years the Bank expanded its business and the reports for 1891 and

\footnotetext{
${ }^{23}$ Until the monetary unification the Bank's quantitative information is expressed in both Mexican and national or Spanish silver currency. This subject is dealt with in detail below.

${ }^{24}$ BEPR, Memoria (1891), p. 16.

${ }^{25}$ BEPR, Memoria (1891), p. 7.

${ }^{26}$ Bank officials believed it was necessary to proceed without delay to the "canje", the term used to refer to the replacement of the Mexican currency for a national one, BEPR, Memoria (1891), pp. 10-11.

${ }^{27}$ BEPR, Memoria (1891), p. 7.
} 
1892 reiterated "the prosperous progress of the Bank and its solid position" ${ }^{\text {"28 }}$. In 1893 the economic and monetary crises in the United States stroke as well the economy of the Antilles. Commercial failures in the New York stock market in May were followed by a scramble for liquidity and runs led to the failure of many banks throughout the country. Moreover, the retarded impact of the higher duties imposed by the McKinley Tariff reduced the US demand for imports. Puerto Rico did not escape from the crisis. Exports to the US market were not a trifle since they represented more than a 20 per cent of all of the island's foreign sales. And as sugar and coffee exports fell, the economy of the colony was severely hit. The balance of trade deteriorated and the silver peso depreciated a 24 per cent to the dollar, which caused a rampant inflation, and vociferous protest and riots in the city of San Juan. As a result the Bank's progress was checked, even though its directors continued referring to the prosperity of the institution 29.

Figure 1 shows that total assets recorded a notable increase during the first two years and then stagnated ${ }^{30}$. In Mexican pesos, they rose from 1.1 million in 1890 to 3.0 million in 1892 and 3.3 million in 1894. The trend in national currency was similar, although the turnover was lower. Overall, assets (in Mexican and national currency) more than doubled from 2.1 million to 5.3 million pesos in 1894 . The balance sheets reveal the pure commercial nature of the Bank, which from the beginning specialized in short-term operations, avoiding involvement in long-term financing or with the island's Treasuy. On average, loans and discounts accounted for 50 per cent of its business operations. As in the case of most banks of the period, including the Cuban issuer, the Español de Puerto Rico maintained a relatively high cash reserve (in Mexican pesos).

Figure 2 and the data in the appendix (table A1) show that the paid-up capital, 25 per cent of the nominal capital, did not change in these five years and the reserve fund was kept at the minimum (15 per cent of the paid-up capital). The stipulation that banknotes should be denominated in national currency did not prevent the Bank from releasing an increasing quantity of paper onto the market: in 1892, issue reached the maximum permitted by its statutes (three times the paid-up capital). In this year, the volume of its national peso reserves fell below the legal requirements, which explains why, in ensuing years, the Bank withdrew notes from the circulation and strengthened

\footnotetext{
${ }^{28}$ BEPR, Memoria (1892), p. 5, and Memoria (1893), p. 5.

${ }^{29}$ The crisis in the US, Milton Friedman and Anna Schwartz, A Monetary History of the United States, 1867-1960. Princeton University Press, 1971, pp. 104-113. The reference for Puerto Rico in Guillermo Baralt, Tradición de futuro, p. 17, and BEPR, Memoria (1894), p. 5, and Memoria (1895), p. 5.

${ }^{30}$ The Bank's balance sheets and income statements in the appendix.
} 
its national currency cash reserves. On the other hand, the Bank's current accounts and deposits recorded steady progress, from one million pesos in 1890 to 2.2 million in 1894.

The evolution of the Bank's income exhibits a similar pattern (figure 3), increasing in the first two years, falling in 1893 and then recovering previous levels. Net profits also followed an upward trend, except in 1893, the year of the crisis. Between 1890 and 1894, profits increased from 45,000 to 98,000 pesos which allowed a generous distribution of dividends to the Bank's owners. The estimated financial rate of return which in 1890 had been 12 per cent rose to 23 per cent in 1894 (Appendix A5 and figure 4$)^{31}$. However, it is apparent that such high yields were obtained at the expense of a reduction in solvency levels. In an unorthodox policy decision, the Board of the Bank preferred to swell the net benefit rather than deducting from it prudent amounts to form an adequate reserve fund.

During this initial phase the Bank's directors were able to present to shareholders some achievements which justified their optimism. In 1891, they extended the activities of the institution beyond the capital city with the opening of a small agency in Mayagüez, which became a branch a few years later. They planned to open another at Ponce, but their application to the government in Madrid fell on deaf ears, perhaps because of opposition from the same local interests which had been responsible for checking financial initiatives in the past ${ }^{32}$. One plan which did come to fruition was the purchase in 1893 of a building at number 3, Tetuán Street, to house the Bank's offices ${ }^{33}$.

The Bank's activity had an invigorating effect on the economy if not of the entire island, at least on that of the city of San Juan, its main sphere of operations. The issue of notes contributed to increase the money supply by supplementing the silver and gold coins already in circulation. At no time was the value and convertibility of the notes questioned, providing traders, farmers and landowners with a comfortable and safe means of payment which had not previously existed. The Bank also broke the oligopoly of merchant-bankers and soon succeeded in lowering market interest rates, from their

\footnotetext{
${ }^{31}$ The financial rate of return is usually estimated as the ratio of net benefits to paid-up capital plus reserves. The trend described fits well with the situation of the Puerto Rican economy in those years, as prices of sugar and coffee, the two variables which determined the prosperity of the island, remained relatively stable.

${ }^{32}$ BEPR, Memoria (1892), p. 8; (1893), p. 7, and (1894), pp. 8-9.

${ }^{33}$ BEPR, Memoria (1894), p. 12.
} 
regular levels of 20 percent or more before 1888 to 11 per cent in 1891 and 7 per cent two years later ${ }^{34}$.

The institution's second period of existence was marked by two significant events. The first one was the replacement of the Mexican silver peso for the so-called "provincial" silver peso, a new silver coin minted in Spain, with the consequent disappearance of monetary duality. The second event was the American invasion of the island and the subsequent end of Spanish sovereignty in the autumn 1898.

The withdrawal of the Mexican currency and its replacement by the island's own currency, called the "provincial peso", which was exactly of the same size and fineness as the Spanish five peseta silver coin took place at the end of 1895. This operation closed a long period of monetary chaos marked by the coexistence of coins from different countries ${ }^{35}$. The "canje", as the currency exchange was called, took place in the last weeks of December, and the rate was set at 95 per cent. In other words, 95 cents in the new (provincial) currency were given in return for every Mexican peso surrendered. The operation was carried out smoothly and quickly. By 1896, the old coins had disappeared from circulation and with them, the duality which had existed until that point. An amount equivalent to $6,646,000$ pesos of provincial-minted silver coins was introduced into the economy of the island ${ }^{36}$. The "canje" put an end to what the Bank considered a financial anomaly, namely that its capital was held and its notes issued in a non-circulating currency. As stated in the Report of 1895, with this action the Banco Español became a true issuing institution, and its notes were "an effective and genuine representation of the money of the island". It was hoped that the monetary unification would bring "new lifeblood", an increase in fiduciary circulation and increased business ${ }^{37}$.

The Report of 1896 still reflected the optimism with which the directors of the Bank viewed the future. They referred to "the growing prosperity" of the establishment,

\footnotetext{
${ }^{34}$ BEPR, Memoria (1892), p. 7, and (1893) p. 7. References to the interest in the island, Dietz, Economic History of Puerto Rico, p. 29; Baralt Tradición de futuro, p. 17.

${ }^{35}$ A good monetary history of the island is given in José Julián Acosta, El canje de la moneda de plata mejicana en Puerto Rico (Puerto Rico, 1887).

${ }^{36}$ Gaceta de Madrid, December 8, 1895, Royal Decree of December 6, 1895. Background of the currency exchange in Tomás Castellano y Villarroya, El canje de la moneda en Puerto Rico (Madrid, 1896). The writings of Coll y Toste are the classic reference work, $B H P R$, vol. IV, t. VII, p. 27, and vol. IV, t. VIII, pp. 263-267. From 1889 onwards, the Boletin Mercantil published a large number of articles, documents and reports on the monetary situation. Also, Alberto Sabio Alcutén, "Un rasgo de la política monetaria en tiempo de guerra: el canje de moneda en Cuba y Puerto Rico, 1895-1898", Tiempos de América (1999), 3-4, pp. 3-18.

${ }^{37}$ BEPR, Memoria (1896), pp. 8-9.
} 
justifying their request for a second disbursement from shareholders in order to increase the amount of effective capital to 750,000 pesos. They wanted to prepare the Bank for the future, and place it in the "position to continue to comply with its mission and to be able to accept any properly guarantee operation" ${ }^{38}$. More resources were also needed to raise its level of solvency, which in 1895 had dropped to a disturbing minimum for the time of 7.5 per cent ${ }^{39}$.

The hopes raised by the currency conversion were not fulfilled. In the years that followed, the Bank was faced with difficulties that its Board could not have foreseen. First, the nearby war on the island of Cuba and the economic crisis of 1897, and the following year, the invasion by the United States of America and the change of sovereignty. In addition, sugar prices remained at low levels and the price of coffee plummeted $^{40}$. The Bank was unable to escape the effects of any of these traumatic events, and the tone of the annual reports mirrored the changed circumstances ${ }^{41}$. Figures 1 and 3 show that in 1898 total assets and income were below those recorded three years earlier. No doubt, the fortune of the Banco Español de Puerto Rico had suffered a sharp and unexpected reversal.

The US invasion of the island in April 1898 and the ensuing war, although brief, left a deep mark on the Bank's accounts ${ }^{42}$. In February 1899, the Board referred with drama, to the "severe test" to which the Bank had been subjected as a result of the war, and to its "unavoidable economic consequences for the island." The public lost confidence in its notes and ran to the windows to convert en masse their bills into silver and gold coins. Not knowing the state of the Bank's balance sheets and fearing that it did not hold sufficient cash, some holders even surrendered their notes at a 20 per cent $\operatorname{loss}^{43}$. Total liabilities fell by almost 30 per cent, from 6 million pesos in 1897 to 4.4 million in 1898 and deposits drop by a near 60 per cent, from 2.5 to 1.1 million pesos (largely due to closure of accounts held by Spanish officials). The metallic stock fell by 760,000 pesos as a result of cash withdrawals, and the Bank was forced to retire a large

\footnotetext{
${ }^{38}$ BEPR, Memoria (1897), pp. 5-8.

${ }^{39}$ The solvency ratio is generally estimated as the ratio of paid-up capital and reserves to total bank's assets.

${ }^{40}$ The evolution of sugar and coffee prices in "The BHW04 Commodity Price Index Source Data" http://chrisblattman.com/data/prices/

${ }^{41}$ BEPR, Memoria (1898), p. 5.

${ }^{42}$ The war began on May 12, 1898, when Admiral Sampson attacked the city of San Juan. The US invasion began at the end of July via the ports of Guárnica and Ponce. An armistice was agreed on August 12, and according to the terms of the Treaty of Paris signed on December 10, Puerto Rico was formally transferred to the United States.

${ }^{43}$ BEPR, Memoria (1999), p. 6.
} 
quantity of notes from circulation: between May and December 1898, the monetary contraction, of more than one million pesos, was dramatic ${ }^{44}$. Although the Bank had no difficulty coping with either convertibility or the withdrawal of deposits, it was however compelled to limit all its commercial undertakings, restricting all type of credit, as well as loans and discounts operations. Income in 1898 fell by 30 per cent compared to 1897 and profits declined from 178,000 to 136,000 pesos. The last year of Spanish sovereignty was disastrous for the Puerto Rican issuer.

More worrying was the deterioration in the Bank's assets. Many customers were unable to meet their obligations, others simply went bankrupt, and a large number of loans remained unpaid at maturity. However, instead of recognizing these as potential losses, the directors of the Bank maintained those non-performing assets in the balance sheets at their nominal value. Hence, at the close of 1898, the valuation of loans and investments which appeared on the Bank' s official accounts did not reflect reality: with payment in arrears and poor and overpriced guarantees, the quality of the Bank's assets was dubious. The institution faced a serious mismatched between its short-term liabilities and the market value of its assets. Rather than writing them off or providing the necessary funds to cover for non-performing debts and insolvencies, the directors did not want to admit that the Bank's financial position had suffered a major setback. The published income statement did not evidence either the true situation of the institution: they showed benefits which would not have appeared if good accounting practices had been adopted, and dividends were paid even though the Bank's financial situation did not permit it ${ }^{45}$.

In 1898, Puerto Rico's 400 year long period under Spanish sovereignty came to an end. Until the early nineteenth century, the economy had made little progress. After 1815, the renowned "Real Decreto de Gracia" led to an increase in the population and in the amount of land under cultivation, transforming the productive structure and linking the colony's economy to international markets ${ }^{46}$. Although established very much later, it was hoped that the Banco Español de Puerto Rico would contribute to the economic development of the colony and to the modernization of its financial system. In less than

\footnotetext{
${ }^{44}$ Between May 1st and December 31st, circulation dropped from 2,048,780 to 993,665 pesos. Archivo General de Puerto Rico (AGPR), Departamento de Hacienda. Serie Bancos y Tesorería (DHBT), box 1.

${ }^{45}$ This was recognized in early 1902. Memoria (1902), pp. 5-6. This would be subject to harsh criticism from the US Treasury when, after taking over the finances of the island, the Bank was subjected to rigorous scrutiny.

${ }^{46}$ Accounts of Puerto Rico's economic transformation in the nineteenth century are given in Sánchez Tarniella, La economía de Puerto Rico; De Jesús Toro, Historia económica de Puerto Rico; Bergard, Coffe and Growth, and Dietz Economic History.
} 
ten years, the Bank managed to establish itself as the most important bank (Table 1) and as the only issuer whose notes circulated in San Juan, Mayaguez and Ponce. However, its performance was plagued by difficulties and its growth was less than would have been possible under normal circumstances. At the turn of the century, war and the change of sovereignty paralyzed the activities of the Bank and ended its monopoly of issue. For the Bank a new period began, which will be dealt with in the next section.

Table 1. Financial Institutions in Puerto Rico. Total resources. In millions of pesos

\begin{tabular}{|l|c|c|}
\hline & 1895 & 1898 \\
\hline Banco Español de Puerto Rico & 4.6 & 3.9 \\
\hline Banco Territorial y Agrícola & 2.3 & 3.0 \\
\hline Crédito y Ahorro Ponceño & 0.4 & 0.8 \\
\hline Banco Popular de Economías y Préstamos & 0.03 & 0.05 \\
\hline
\end{tabular}

Source: Santiago de Curet, Crédito moneda y bancos, pp. 73-77, and the appendix.

Figure 1. Banco Español de Puerto de Rico: Total and Commercial Assets, 1890-1899 (Thousands of pesos)

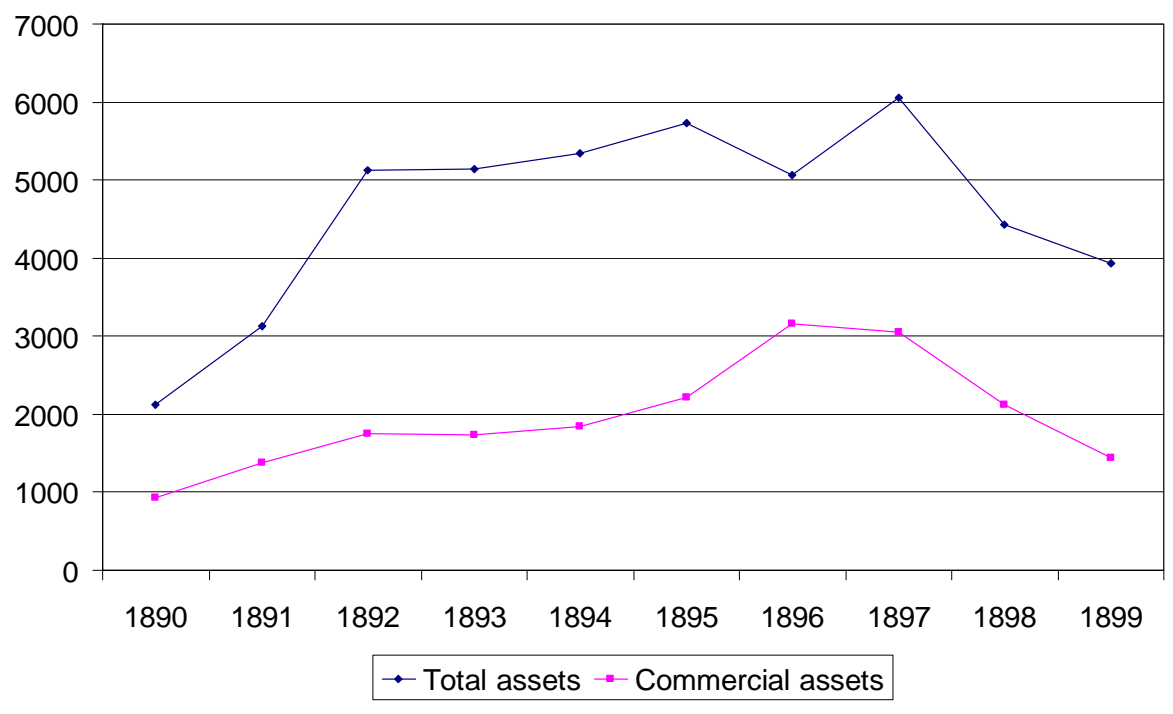

Source: Appendix. 
Figure 2. Banco Español de Puerto Rico: Capital, Banknotes, Current Accounts and Deposits, 1890-1899 (Thousands of pesos)

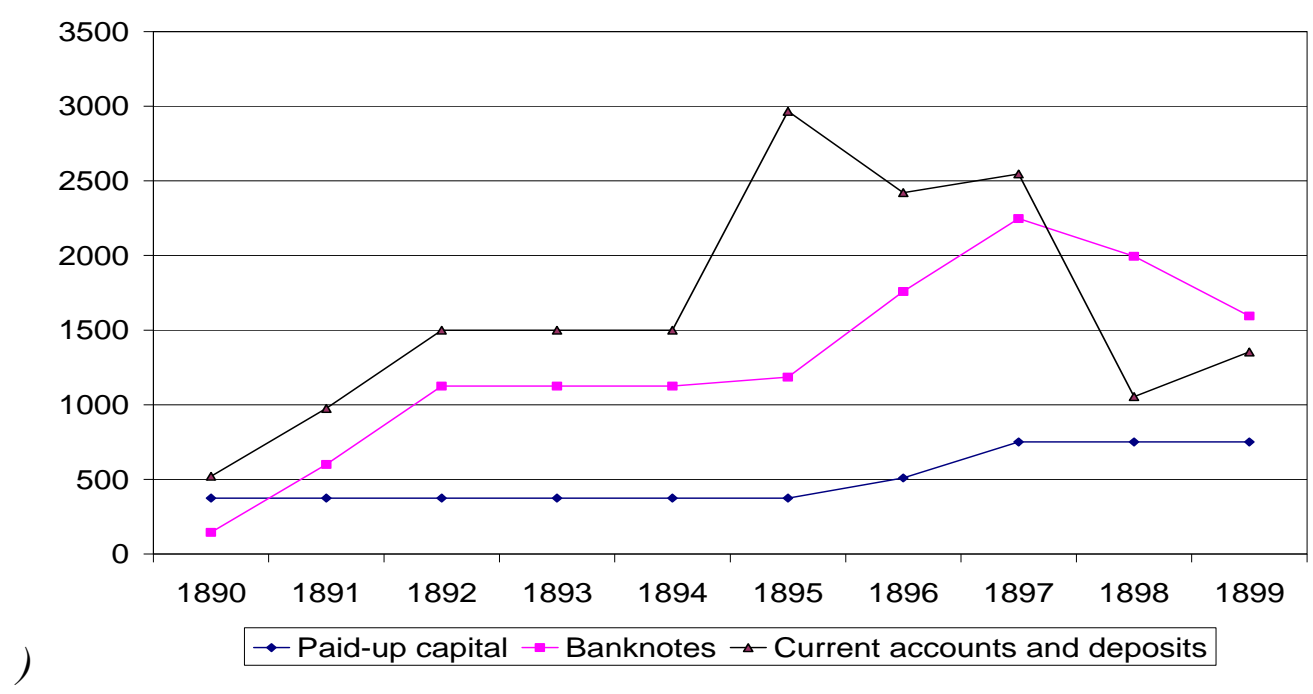

Source: Appendix

Figure 3. Banco Español de Puerto de Rico: Income, Losses and Profits, 1890-1899 (Thousands of pesos)

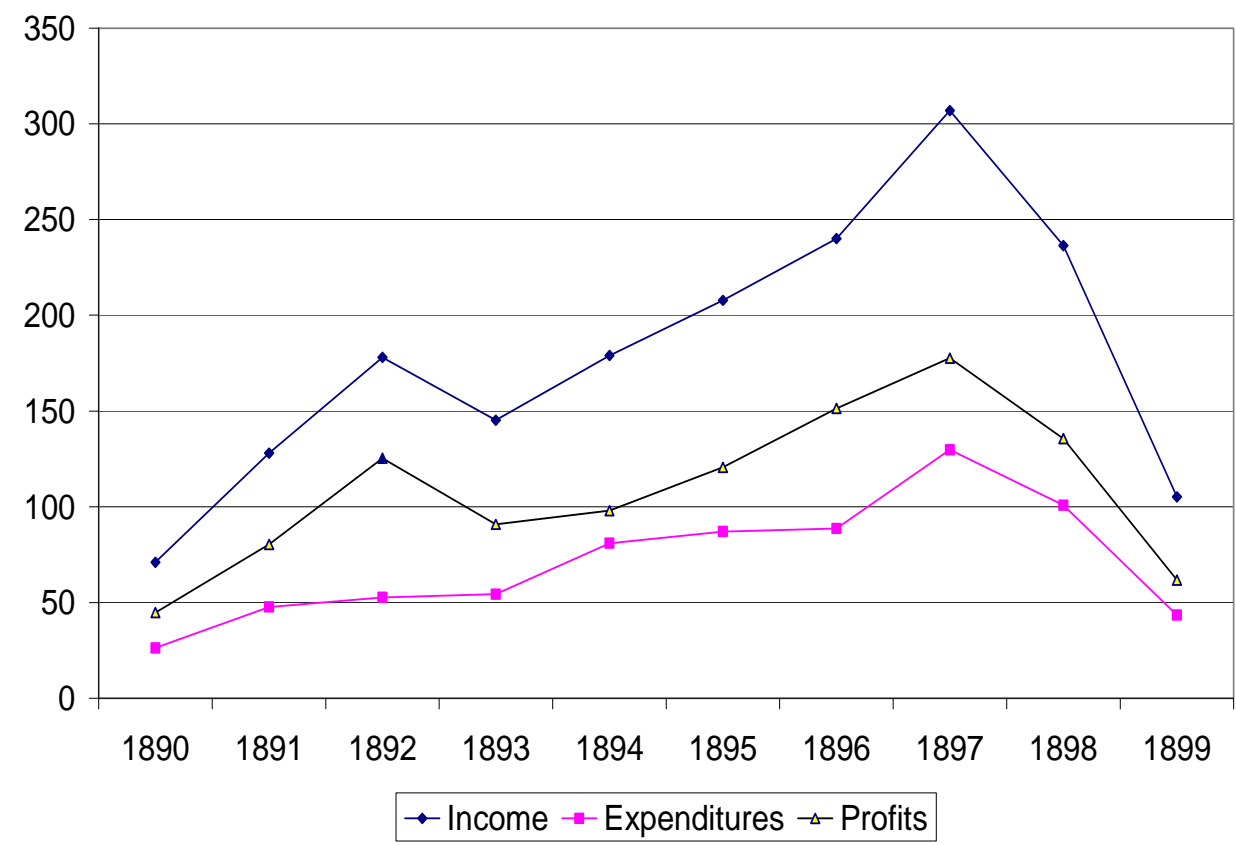

Source: Appendix 
Figure 4. Banco Español de Puerto de Rico: Return on Equity (ROE) and Solvency ratio, 18901899

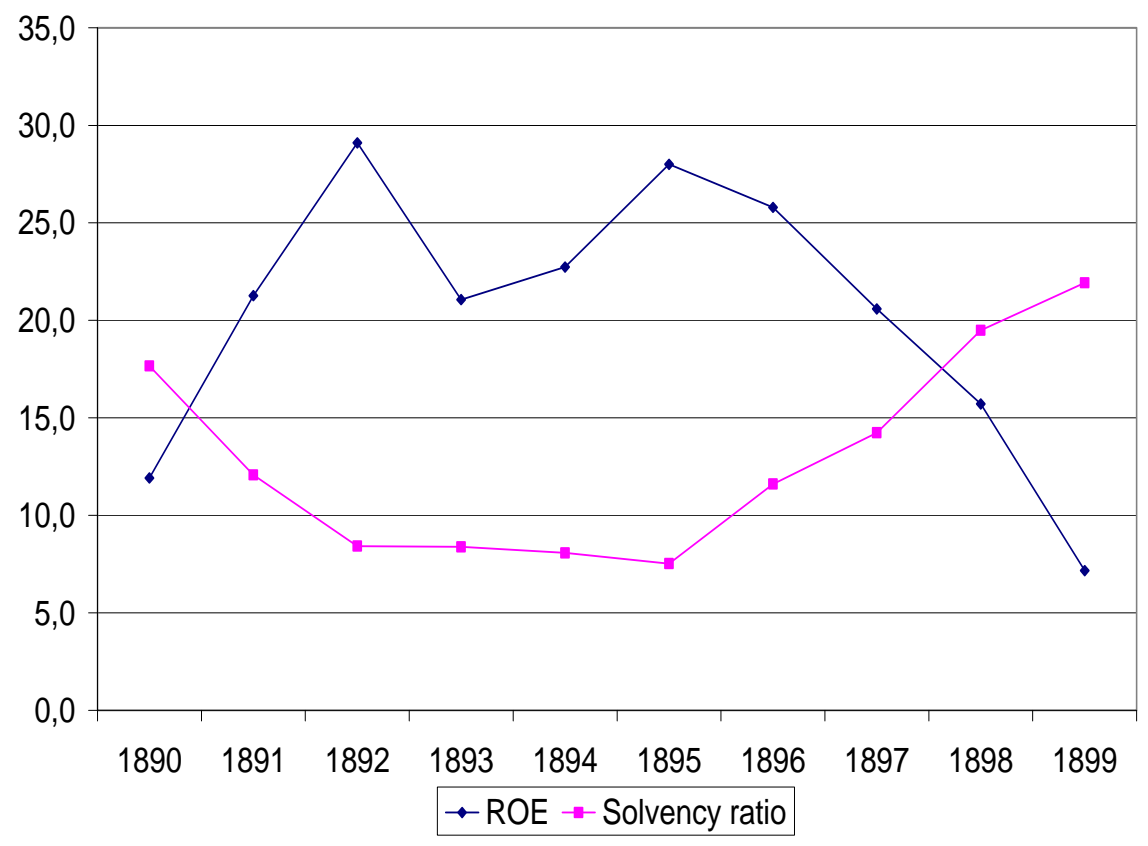

Source: Appendix

\section{Strain under US sovereignty: 1899-1905}

With the withdrawal of her troops from San Juan, Spain formally released Puerto Rico in October 18, 1898. The US civil and military officials found their new possession poor and its economy extremely underdeveloped ${ }^{47}$. They also found that the Puerto Rican banking structure was at odds with the US banking system, characterized by the existence of a few big credit institutions based in the major cities together with thousands of small scale credit firms scattered throughout the country ${ }^{48}$. Contrary to the common situation in Europe, there was no central or issue bank and the dollar bills were issued by the Treasury. In one of his reports, one of the commissioners that visited the island at the time, Henry Carroll, stated that only a few financial institutions and a

${ }^{47}$ Report of Brigadier-General George W. Davis on the Civil Government of Puerto Rico. Industrial and Economic Conditions (Washington, 1899). Content is based on information provided by Coll y Toste in Reseña del estado económico e industrial de la isla de Puerto Rico (Puerto Rico, 1899). Also Victor S. Clark, Porto Rico and Its Problems (Washington, 1930), pp. 374-375, and William Dinwiddie, Puerto Rico: its Conditions and Possibilities (New York, 1899).

${ }^{48}$ A classical account of the US banking system in Charles A. Conant, A History of Modern Bank of Issue (New York, 6th edition, 1927), chapter XV. Recently, Richard S. Grossman, Unsettled Account: the evolution of banking in the industrialized world since 1800 (Princeton, 2010), pp. 230-243. 
poorly capitalized issue bank with an incomprehensible privilege were operating in the island. He recommended the immediate implementation of the federal banking legislation and the establishment of banks in accordance with the National Banking $\operatorname{Acts}^{49}$.

The change of sovereignty was an event with consequences for the Banco Español de Puerto Rico which it would be difficult to overstate. The Bank entered a period of uncertainty. The Board did not know what attitude the US administration would take towards the institution and feared for the Bank's immediate future. Their concerns were exacerbated by strained relationships with Treasury Department officials, monetary problems arising from the enforced exchange of local currency for the dollar, and the arrival of strong competitors in the form of foreign banks. Other factors were the devastating effects of the San Ciriaco hurricane that struck the island in August 1899, the falling price of sugar and coffee, and what Fernando Pico has rightly called, "the war after the war," a social and economic crisis that for some time disrupted the internal order and normal operation of estates and commerce ${ }^{50}$. The truth is that for nearly five years, the Bank remained at a standstill.

In the economic sphere the urgent question was the substitution of the local currency by the dollar, because as soon as the US troops landed on the southern coast of the island, the dollar began to circulate alongside the peso. At the port of Ponce, the head of the military command passed a mandatory order fixing an exchange rate of two pesos to one dollar. Trumbull White, in Puerto Rico at the time, pointed out that it soon became evident in Ponce and elsewhere that transactions were taking place not at the official rate but at a fluctuating one. In shops and stores, the military order of "two for one" had no effect at all. Although it was possible to obtain 1.90 pesos for a dollar from the banks and the money-changers, the rate usually was far below that, at around $1.75^{51}$.

The increase in the quantity of money and the confusion introduced by the floating rate led to a rapid deterioration in the standards of living. Prices rose while the uncertainty resulted in the postponement of consumption and investment decisions. This

\footnotetext{
${ }^{49}$ Henry K. Carroll, Report on the island of Porto Rico (Washington, 1899), pp. 52-53.

${ }^{50}$ Fernando Picó, La guerra después de la guerra, (Río Piedras, 1987). For the results of the transfer of sovereignty and the devastating effects of the hurricane, see Irene Fernández Aponte, El cambio de soberania en Puerto Rico (Madrid, 1999), pp. 136-160; pp. 227-238; Dietz, Economic History of Puerto Rico, p. 89 et seq. Brief contemporary references in Salvador Brau, Historia de Puerto Rico (New York, 1904). Also Edward J. Berbusse, The United States in Puerto Rico, 1898-1900 (Chapel Hill, 1966), pp. 127-129, and Arturo Morales Carrion Puerto Rico. A political and cultural history (New York, 1983), chapter 8 .

${ }^{51}$ Trumbull White, Our new possessions (Chicago, 1898), pp. 427-428, and Dinwiddie, Puerto Rico: its conditions, pp. 214-224. Also Report of General Davis, pp. 239-240.
} 
prompted the US administration to take measures to resolve the problem. Carlos Soler, deputy director of the Banco Español de Puerto Rico, wrote a report for the military governor, General George W. Davis, in which he admitted that given the relatively small volume of local money in circulation, the shift to the US dollar would not pose major difficulties. The crucial question was not the currency exchange itself, but rather the selection of the rate of exchange: if this were fixed at par, one peso for one dollar, obviously the creditor would profit, while debtors would suffer a considerable loss. However, if the rate were fixed at "two for one", the debtor would benefit at the expense of the creditor. Soler proposed an exchange rate of US\$ 0.75 the peso, which he considered an intermediate position satisfactory to all parties ${ }^{52}$.

For his part, the Treasury Secretary, Lyman Gage, sent a special commissioner, Robert P. Porter, to San Juan with the mission to prepare a report on the question of the exchange. Porter met with bankers and merchants of the island to hear their opinions. The commissioner recommended transplanting the US monetary system as soon as possible and proposed an exchange rate of US\$ 0.60 for one Puerto Rican silver peso, or 1.66 Puerto Rican money for one US\$, a rate substantially more favorable to the local currency than Soler's proposal ${ }^{53}$. It would be difficult to exaggerate the influence of Porter's report: within a few days his recommendation had been accepted by President William McKinley, who transmuted it into the Executive Order of the Mansion House of January $20,1899^{54}$. The adoption of the dollar as the unit of account in the Bank's accounts was introduced in 1900.

Fears about the future of the Bank slowly began to fade. First, reassurance came in the form of the appointment on October 17, 1899, of John D. H. Luce, a prominent US banker familiar with the economy and finances of the island, to the office of

\footnotetext{
${ }^{52}$ El canje de la moneda en Puerto Rico. La opinión del Banco Español de esta Isla (Puerto Rico, 1898).

${ }^{53}$ Report on the Currency Question of Porto Rico by Robert P. Porter, special commissioner for the United States to Cuba and Porto Rico (Washington, 1899), Henry Carroll (Report, 1899) also dealt with the conversion and called attention to the different views held on the island. An excellent summary of the conversion in Di Venuti, Money and Banking, pp. 14-22; also Emily S. Rosenberg, "Foundations of the United Sates International Financial Power: Gold Standard Diplomacy, 1900-1905", Business History Review, 59, 2 (1985), pp. 172-176. For Cuba, José A. Piqueras, "El periodo interventor y la dolarización de Cuba", in Martín Rodrigo y Alharilla (ed.), Cuba, de colonia a república (Madrid, 2006), pp. 167-189. ${ }^{54}$ BHPR, VIII, VI, 1918, pp. 104-105. To speed up the replacement of the peso for the dollar, section 11 of the Congress's First Organic Act of Porto Rico of May 1, 1900 (the so-called Foraker Act) ordered the withdrawal of the Porto Rican coins in circulation and authorized the Secretary of the Treasury to redeem them on presentation at the established official rate. The withdrawal of Puerto Rican currency in First Annual Report of Charles H. Allen, Governor of Porto Rico (Washington, 1901), pp. 65-66.
} 
governor while Soler continued as deputy director ${ }^{55}$. Later, the Joint Resolution of the United States Congress $247 \mathrm{H}$ of June 6, 1900, confirmed the continuity of the Bank until the end of its franchise ${ }^{56}$. However, although the Bank was not divested of its right to issue, neither was it granted the exclusive right it had enjoyed under Spanish sovereignty. It continued as an issuing entity, but this right quickly proved to be economically and financially meaningless, since in practice the Bank was reduced to the simple status of an ordinary credit institution. The directors themselves recognized this:

"Before the war, our Bank held sole right to issue and as the state did not exercise banking functions, so to speak, its notes were the only ones in circulation on the island. However, now that the government's notes enjoyed the status of legal tender, it cannot be denied that the Bank's privileges have been limited by the Joint Resolution of June 6, 1900 in so much as the circulation of our notes cannot circulate as widely as they once $\operatorname{did}{ }^{27}$.

Supplanted by the US dollar bills, the Bank's notes although denominated in dollars, became a second class means of payment. Likewise, the right to issue granted in 1902 to the First National Bank of Puerto Rico, established under US law came as a harsh blow. The embittered reaction was immediate:

"The Banco Español de Puerto Rico, which has never performed a single act that could be interpreted as hostility toward any of the island's other banking institutions, considering that this issue infringed on their legitimate rights [...] has been forced to resort to self-defense by presenting a formal protest before the said bank and before with the Comptroller of the Treasury in Washington" ${ }^{58}$.

The protest led nowhere, and the Bank had to acknowledge that both "de jure" and "de facto" it no longer enjoyed the exclusive right to issue banknotes. The best evidence of the diminishing role of the Bank's money is the evolution of its notes in circulation. The figures are very telling: US\$ 956,000 in December 1900, US\$ 630,000 in December 1905 and US\$ 375,000 in December $1912^{59}$.

\footnotetext{
${ }^{55}$ Luce was replaced in 1905 by Manuel Paniagua, who remained at the head of the institution until its dissolution.

${ }^{56}$ Under the terms of the JR247H, the Bank was authorized to amend its statutes to change its name, replace its capital in pesos for equivalent in dollars at the established exchange rate, to remove the Spanish nationality requirement for the governor and to make whatever changes were necessary to adapt the institution to the financial laws of the United States. However, the Foraker Act said nothing about the Bank's notes in circulation, nor about the institution's right to issue.

${ }^{57}$ BEPR, Memoria (1902), p. 8.

${ }^{58}$ BEPR, Memoria (1903), p. 9.

${ }^{59}$ In fact, the volume of notes actually in circulation was lower: 407,313 and 395,958 in December 1900 and 1905, AGPR, DHBT, box 1, "Issue of Bank Notes by the Banco Español de Puerto Rico".
} 
Moreover, from the moment the US Treasury officials took over the supervision of banking on the island, they showed a more than apparent distrust for the Banco Español and its directors. They did not like its note-issuing status, so alien to the US system, and put pressure on the Bank to reduce the volume of bills in circulation and to cover them and all short term liabilities (current accounts and demand deposits) in accordance with US legislation. For the US Treasury, the Banco Español's notes had no sense as they were neither legal tender nor were they quoted in foreign exchange markets ${ }^{60}$. Neither did the Treasury officials like the Bank's unorthodox accounting methods, holding bad debts and loans on the balance sheet, or the lack of transparency in their accounts, which did not provide an accurate picture of the Bank's financial position. They furthermore disliked the Bank's practice of distributing dividends out of reserves, without making provisions to cover non-performing assets and potential defaults ${ }^{61}$.

The Bank's report of 1903 indicated that relations with the Treasury were less than ideal:

"Given that the public administration was at first ignorant of the history of our institution and was furthermore astonished by the novelty of our capacity of issue, which is based on different principles to those underlying US banking practices, it is not surprising that in recent years our notes have been viewed with some suspicion in certain official quarters" ${ }^{62}$.

The arrival of new credit institutions also took its toll on the performance of the Banco Español. Following the armistice, the bank De Ford \& Co. of Boston opened an office in 1898 with a capital of US\$ 200,000. Moreover, De Ford was appointed United States government auditor for the island and official deposits, including those of the army. From 1899 onwards, more banks opened branches in San Juan: the US Colonial

\footnotetext{
${ }^{60}$ The extensive correspondence between Soler and island Treasury officials, especially with the first of these, Jacob H. Hollander, and his successor, William F. Willoughby, attests to the mistrust of these latter. Soler was forced to provide continuous explanations of the Bank's operations and submit all kind of documentation and weekly information with the balance sheets and the income and loss accounts. AGPR, DHBT, box 3: also First Annual Report, pp. 195-197, and Second Annual Report by William H. Hunt, Governor of Porto Rico (Washington, 1902), pp. 158-161.

${ }^{61}$ AGPR, DHBT, box 1, "Memorandum on the Spanish Bank of Porto Rico." See also the letter "From the governor of Porto Rico to the Governor of the Bank of Porto Rico, May 5th, 1905, in which the latter was instructed not to distribute dividends to the share-holders without official authorization, to reduce banknote issue, to make up the deficiency in the reserve fund, and to remedy the impairment of its capital. The unease of Treasury officials concerning the Bank was evidenced on numerous occasions: First Annual Report, pp. 67-68.

${ }^{62}$ BEPR, Memoria (1903), pp. 9-10.
} 
Bank of Puerto Rico, with a capital of US\$ 1 million, followed by the First National Bank of Puerto Rico in 1903 and the Union Bank of Halifax in $1906^{63}$.

The five years between 1899 and 1904 were, thus, financially and economically complicated. Sugar prices fell by 20 per cent and the trend in coffee prices was even more negative. Exports barely increased ${ }^{64}$. The policy followed by the directors of the Bank was to preserve the capital, minimize the risk of losses and avoid circumstances that would endanger the solvency or liquidity of the institution. To this end, they opted to reduce the Bank's financial activity, limiting it to the renewal of loans, to discounting very short-term paper and to stopping the drain on their current accounts. However, they failed to prevent rising the number of defaults by landowners and merchants affected by the economic crisis, the hurricane and the fall in export prices ${ }^{65}$. The Bank's annual reports echoed the hard economic and financial times through which the island was passing through and their impact on the Bank's balance sheets and income statements ${ }^{66}$.

As can be seen in figures 5 and 6, and the appendix, total assets fell from US\$ 2.4 million in 1899 to US\$ 1.7 million in 1905. The balance sheet showed scant movement of discounts, loans and credits of all kinds: the lack of demand on the one hand, and the limited financial capacity of the institution itself, on the other, explained this sluggish state of affairs. Current accounts and deposits fell sharply to below half a million dollars also as a consequence of the political and economic crisis. Even more serious was the already mentioned decline in banknote issue, which fell from US\$ 956,000 to US\$ 630,000. However, the paper currency actually in circulation, in other words, in the hands of the public, was much lower: US\$ 407,313 in 1899 and US\$

\footnotetext{
${ }^{63}$ A complete list in Baralt, Tradición de futuro, p. 43; the arrival of new entities in the Sixth Annual Report of the Governor of Porto Rico (1906), pp. 22-23, and Seventh Annual Report of the Governor of Porto Rico, 1907, p. 13. Also, Thomas C. Cochran, The Puerto Rican Businessman. A study in cultural change (Philadelphia, 1959), pp. 36-40.

${ }^{64}$ The economy in the early years of US sovereignty in Dietz, Economic History of Puerto Rico, pp. 79134, for the external trade figures between 1900 and 1913, Di Venuti, Money and Banking in Puerto Rico, p. 302. The figures are from A. D. Gayer, Paul T. Homan and Earle K. Jones, The sugar economy of Puerto Rico (New York, 1938), table 30, p. 79.

${ }^{65}$ BEPR, Memoria (1900), pp. 5-8.

${ }^{66}$ BEPR, Memoria (1901), pp. 6-11, mentions "the present distress of our agriculture" and the reduction of metal stock due to the repatriation of Spanish military and civilian personnel who took 600,000 pesos with them, and also the consequences of the war, the effects produced by the prices of the country's products, and the evils caused by the cyclone of 1899 and subsequent flooding. The 1902 Memoria reiterated the stagnation of production due to the low sugar and coffee prices. The Bank closed the Mayagüez branch, replacing it with a simple auxiliary office. The Memoria of 1903 (p. 6) stated that the "island is completely bankrupt or ruined", an extreme situation that led the Bank to lease a portion of its building.
} 
359,958 in 190567. Instead of increasing its financial capacity, the Banco Español de Puerto Rico lost deposits and many of its former clients. The income and loss statements of those years were also witness of the stagnation of the institution. The Bank never closed in the red, but its income plummeted and with them, so did its profits, from US\$ 37,100 in 1899 to US\$25,000 million in 1904. The rate of returns of the past melted away, reaching levels of below 10 per cent (figures 7 and 8 , and appendix).

Figure 5. Banco de Puerto de Rico: Assets, 1899-1912

(Thousands US dollars)

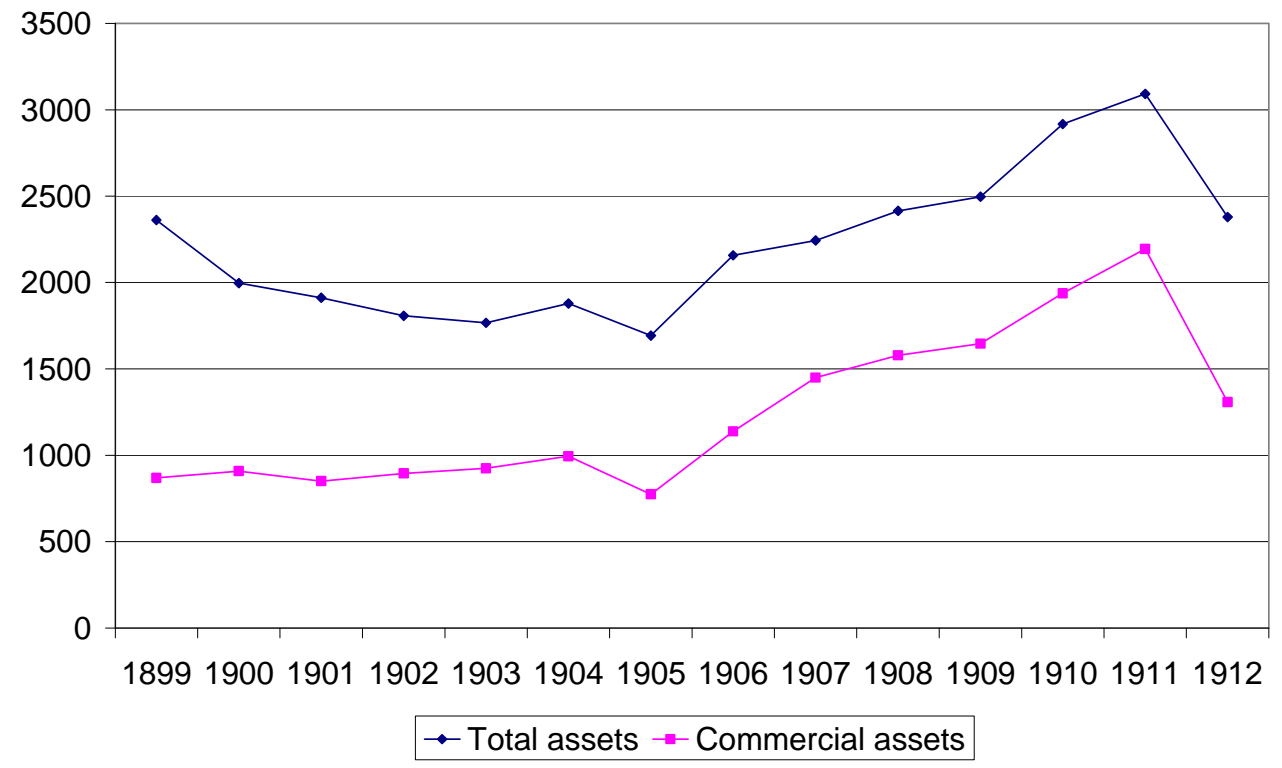

Source: Appendix

\footnotetext{
${ }^{67}$ Bank issue and notes in circulation between May 1898 and June 1906 appear in a statistical analysis compiled by the entity itself and submitted by Soler to the Island's Treasury officials, AGPR, DHBT, box 1.
} 
Figure 6. Banco de Puerto de Rico: Capital, Reserves, Banknotes and Deposits, 1899-1912 (Thousands US dollars)

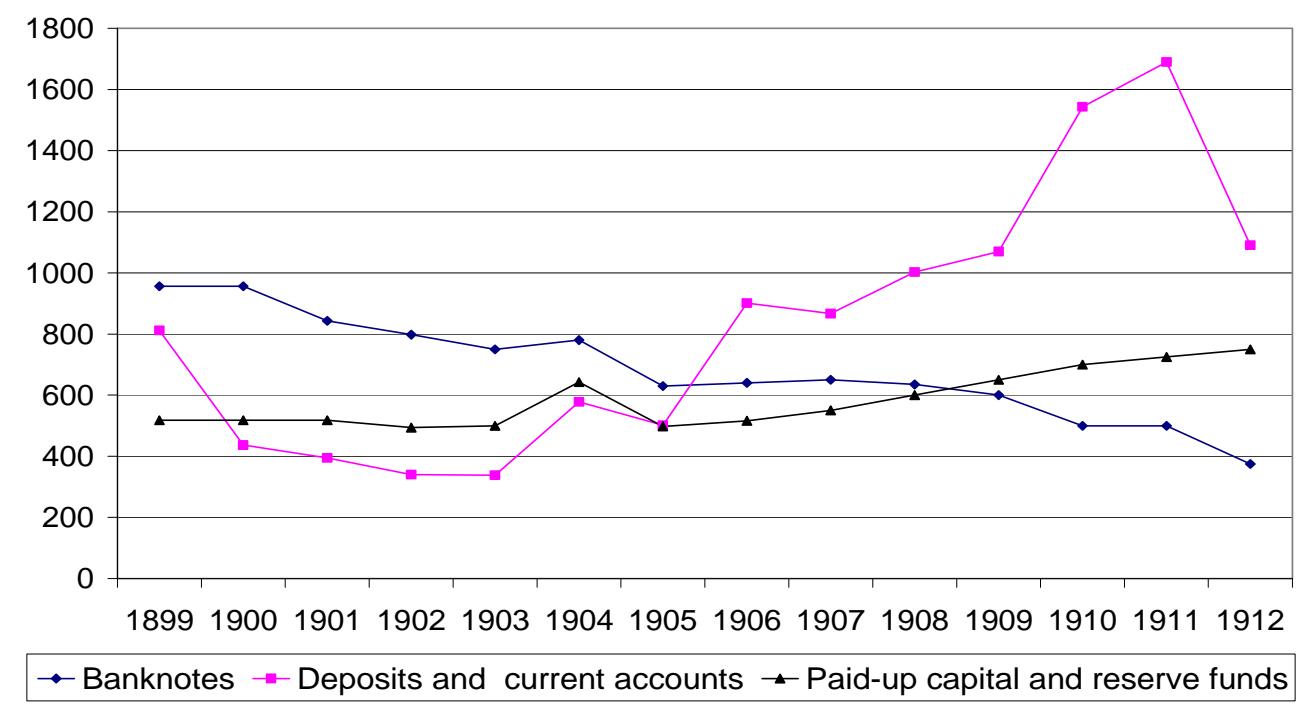

Source: Appendix

\section{Prosperity under US Sovereignty: 1906-1913}

The course of the Banco Español de Puerto Rico improved, as might be expected, when the economic climate of the island changed and when the internal obstacles that had paralyzed its administration were resolved. Both factors coincided in time, and from 1906 until the end of its days, the Español de Puerto Rico enjoyed a final period of prosperity. Sugar prices began to recover slowly and, after the nadir of 190708, coffee prices experienced a sharp rise. Exports increased from US\$ 18.7 million in 1905 to US\$ 38.0 million in 1910, reaching US\$ 49.7 million in 1912. The trade balance closed with a continuous series of surpluses. The economy of the island also received a significant influx of US capital ${ }^{68}$.

In 1905, William F. Willoughby, head of the island Treasury requested a detailed examination of the Bank's accounts and a report on its financial position, and commissioned the audit firm Haskin and Sells from New York to carry this out. The report prepared by the latter was devastating and confirmed the suspicions of the US administrators. The volume of non-performing assets was astonishing, nearly half the paid-up capital. But the worst finding was unquestionably the lack of provisions for

\footnotetext{
${ }^{68}$ Harvey Perloff, Puerto Rico's Economic Future (Chicago, 1950), pp. 27-29.
} 
defaults combined with dividend payments made against incorrectly recorded profits. To clean up the balance sheet, the auditors recommended removing non-performing assets and uncollectible debts, estimated at US\$200,000, and reducing the capital by the same amount. They further recommended strengthening reserves against profits, that part of the reserves should be invested in Treasury bonds and that the Bank should strictly observe statutory financial ratios. Willoughby accepted the auditors' recommendations, although he limited the amount of impaired assets to US\$ 150,000 . Consequently, the original authorized capital of US\$ 900,000 (equivalent to 1,500,000 silver pesos) and represented by 15,000 shares, was reduced to US $\$ 750,000$ by cutting the value of each share from US\$ 60 to US\$ 50, a loss that was borne by the shareholders. The paid-up capital was kept at US\$ 450,000, leaving the remaining US\$ 300,000 outstanding. It was established that the Bank would hold United States Treasury bonds and notes and gold and silver coins or bars, for at least a third of the amount of the Bank's notes in circulation, and the other two thirds in preferred stocks ${ }^{69}$. The operation took place in December 1905, and Manuel Paniagua, appointed governor of the Bank in November 1905, and the deputy director, Soler, carry out the task. At the same time new statutes were approved and the name of Banco de Puerto Rico eventually adopted ${ }^{70}$.

With the occasion of the reform, the Bank's directors drafted an extensive report reviewing the main problems that the Bank had faced since the handover of sovereignty. It was acknowledged that the institution had not enjoyed the trust of the metropolitan authorities, due "in part to the special conditions of our banknote issue, based on principles that are a novelty for the (US) government, given the established legal system regarding issue by US banks". It was admitted that the entry and use of the US notes had been a harsh blow. Likewise, it was acknowledged that the institution had suffered a sharp decline in its current accounts as a result of the withdrawal of Spanish officials and the cancellations deposits by Spanish civilians and military personnel. Furthermore, it was recognized that the substantial losses, hitherto unaccounted, were the result of the exceptional circumstances caused by the war, the devastating impact of the hurricane Ciriaco, the simultaneous decline in coffee prices, and suspension of payments by important companies in the city of Mayaguez. It was also admitted that the deterioration

\footnotetext{
${ }^{69}$ AGPR, DHBT, box 3, contains the audit documentation.

${ }^{70}$ The change in name was envisaged in the Joint Resolution, but was delayed until 1905.
} 
of the financial position of the Banks had put its capital and its solvency in grave danger ${ }^{71}$.

Once the statutory changes had been effected and the portfolio of the Bank clean up, the relationship between the Bank directors and the US administrators improved, and tensions disappeared. The latter felt that now the institution complied better with the financial legislation of the metropolis, and hence fears about its solvency were dispelled. The new mood was also a consequence of the substantial decrease in the amount of Bank's notes in circulation, the permanent preoccupation of the US Treasury officials. As stated by the President, Manuel Paniagua, the Bank entered into a "new era", although this was to be short lived ${ }^{72}$.

The Bank's annual reports provide good evidence of the changed circumstances. The 1905 report mentioned the increased activity of the Bank, fruit of the economic recovery of the island. The report for 1906 was optimistic in tone, speaking of "greater development of public wealth and the promotion of new businesses that demanded new lines of credit." In 1907, the report stated that the island was not affected by the serious crisis of that year, and referred to "unwonted business development" and to the continuing increase in production as new means of communication opened and the sugar mills extended their scope of action. In the same year, an auxiliary office was established in Ponce. In the report for 1908, the directors again referred to "the island's growing prosperity [...] raises hopes that the year will be at least as fruitful for the Bank as was that which has just ended"73. A good proof of the promising evolution of the Bank is that its shares were quoted above par, with a premium of 15 per cent. In the 1909 report, the directors complained that the limitations on the Bank's resources (its small paid-up capital and the limits imposed on the volume of its banknotes in circulation) prevented the Bank from competing on an equal footing with the other financial institutions on the island. Again evidence of the progress of the institution is that by the end of the decade its share prices had already reached a premium of 44 per cent over its nominal value. And the 1911 report (the penultimate) stated that the Bank's

\footnotetext{
71 "Banco de Puerto Rico, Informe leído a la Junta General Extraordinaria de Accionistas, celebrada en 14 y 16 de diciembre de 1905", in BPR, Memoria (1906). Paniagua personally informed the governor of the island of the changes, "Letter from M. Paniagua to Hon Beckman Winthrop, Governor of Porto Rico, May 15, 1906 ", AGPR, DHBT, box 3. The statutory changes in "Amendments made to the by-laws of the Spanish Bank of Porto Rico, According to the Joint Resolution of June 247H 6, 1900", AGPR, DHBT, box 1.

${ }^{72}$ For Paniagua the "new era" meant that eventually the bank would comply with American regulations.

${ }^{73}$ BPR, Memoria (1909), provides a breakdown of the loan portfolio: trade (43\%), sugar mills (22\%), agriculture $(13 \%)$ and industry and individuals $(22 \%)$.
} 
performance and increasing wealth was due to the "flourishing economic situation of the island", with foreign trade figures that continued to rise $\mathrm{r}^{74}$.

The balance sheets are again a good test of the financial evolution of the Bank. As shown in figure 5 and the appendix, total assets recovered to reach US\$ 3.1 million in 1911, still a relatively small amount, but enough to enabled the institution to maintain its standing as one of the leading banks on the island: its assets represented 17 per cent of the consolidated balance sheet of the country's financial institutions, the largest of which were the US Colonial Bank, the Royal Bank of Canada and the Banco Territorial y Agricola, but with few differences (Table 2) ${ }^{75}$. The Bank's growing activity stemmed from its core operations: the discounting of commercial bills and short-term loans. The Banco de Puerto Rico continued, like its predecessor the Banco Español de Puerto Rico, to be a strictly deposit institution, specialized in commercial credit. It refrained from getting involved in long-term financing, or in industrial investment, and neither maintained any commercial relationship with the Treasury of the island.

On the liability side, both and figure 6 and table A3 show that most of the Bank's financial resource came out from an increase in its current accounts and deposits, which tripled between 1905 and 1911, while the volume of its banknotes in circulation declined steadily. In 1912, the US\$375,000 was far from those recorded in 1900, and well below the amount the paid-up capital. Thus, the Bank was a kind of strange issuer whose notes barely circulated, and were only used to a limited extent as a means of payment in the city of San Juan. They were a relic from the past that the US Treasury officials were prepared to tolerate until the Bank was liquidated.

Income tripled between 1905 and 1911, while profits quadrupled, from US\$ 25,000 in 1904 to US\$109,000 in 1911 (figure 7 and table A4). The rate of return that had fallen to its lowest record in 1904 rose again and by 1906 the yield estimates was already above 10 per cent, and in 1911 they reached 15 per cent. The Banco de Puerto Rico was small but very profitable. Moreover, in figure 8, it can be seen that solvency and profitability followed opposite trends until 1904, as in the previous period of Spanish sovereignty, but that from 1905 onwards, they were moving in the same direction. After the latter date, the solvency ratio was always above 20 per cent, a proof

\footnotetext{
${ }^{74}$ BEPR, Memoria (1905), pp. 5-6, BPR (1907), pp. 5-6, (1909), p. 6, (1912), pp. 5-6. In 1911, the price had a premium of 65 per cent. Improved economic conditions in the Tenth Annual Report of the Governor of Porto Rico (Washington, 1910), pp. 5-8, and the Eleventh Annual Report of the Governor of Porto Rico (Washington, 1911), pp. 5-6.

${ }^{75}$ Eleventh Annual Report: Exhibit 9, p. 108; Twelfth Annual Report, Exhibit 9, p. 128.
} 
of the efforts made by the US administrator in strengthening the institution reserve fund. In fact, whilst the paid-up capital remained at US\$ 450,000, the reserve fund increased from US\$ 50,000 in 1903 to US\$ 300,000 in 1912.

The last meeting of the shareholders of the Banco de Puerto Rico was held in February 1913, three months before the end of the franchise (on May 5). According to Paniagua, faced with the impossibility of extending the Bank's existence due to its foreign (Spanish) origin, a Liquidation Committee was designated to oversee the dissolution of the company ${ }^{76}$. The Commission acted with deliberation, concluding its work in 1925. It settled the outstanding transactions and distributed among the shareholders US\$ 50 per share, the sum of US\$ 30 paid per share plus US\$ 20 out of the accumulated reserve fund ${ }^{77}$. According to the balance sheet of 1912, the Bank's total assets amounted to US\$ 2.4 million, of which about half corresponded to loans and discounts $^{78}$. The Bank appeared healthy and robust, with a high level of solvency (equity over total assets) of 28 per cent. The net profits for the year amounted to US\$ 82,005 , representing a not meaningless return of 10.9 per cent ${ }^{79}$.

Before the official date of dissolution, the Bank's directors and shareholders decided to constitute another financial institution which would continue the business of the old Banco Español. Thus a new financial institution named Banco Comercial de Puerto Rico was born out of the ashes of the former colonial issuer. It was established with a capital of one million dollars, divided into 10,000 shares of US\$ 100 each, of which 7,500 were offered to the shareholders of the Banco de Puerto Rico at par, whilst the remaining 2,500 were sold to the market. To avoid the disruption of business, the Banco Comercial de Puerto Rico opened its doors on November $1,1912^{80}$.

\footnotetext{
${ }^{76}$ However, it was not its foreign nature which forced it to close, as other former Spanish institutions such as the Banco Popular de Puerto Rico, did not close. Rather, it was its issue character that led the US financial authorities on the island to refuse an extension to its franchise. For US officials the end of the franchise gave the opportunity to get rid of an bank they never liked.

${ }_{77}^{7 n f o r m e ~ r e l a t i v o ~ a l ~ B a n c o ~ E s p a n ̃ o l, ~ p p . ~ 20-26 . ~}$

78 This only covers the 10 month period of actual operation of the entity, before the constitution of the Banco Comercial de Puerto Rico in November.

${ }^{79}$ BPR, Memoria (1912), includes a list of the shareholders, indicating their place of residence and number of securities in their hand.

${ }^{80}$ Although the Banco de Puerto Rico was technically liquidated, it can also be argued that it did not disappear since its assets were transferred to a new non-issuing financial institution which was its continuation and its management remained under the same hands. Later on, the Banco Comercial de Puerto Rico defaulted in 1930 and a few years later it was acquired by the Banco Popular de Puerto Rico, a financial firm which dates back to 1893 .
} 
Table 2. Financial institutions in Puerto Rico: total resources. June, 1912 (in millions of dollars)

\begin{tabular}{|l|c|}
\hline BANKS & $\begin{array}{c}\text { TOTAL } \\
\text { RESOURCES }\end{array}$ \\
\hline US Colonial Bank of Puerto Rico & 4.5 \\
\hline Royal Bank of Canada & 3.9 \\
\hline Banco Territorial y Agrícola & 3.7 \\
\hline Banco de Puerto Rico & 3.0 \\
\hline Crédito y Ahorro Ponceño & 1.1 \\
\hline Bank of Nova Scotia & 0.4 \\
\hline Banco Popular de San Juan & 0.3 \\
\hline Caja de Economías y Préstamos de San Germán & 0.3 \\
\hline Crédito y Ahorro Popular de Yauco & 0.06 \\
\hline Caja de Economías y Préstamos de Cabo Rojo & 0.05 \\
\hline Caja Popular de Ahorros y Préstamos de San Germán & 0.02 \\
\hline Total resources & 17.3 \\
\hline
\end{tabular}

Source: Eleventh Annual Report, Exhibit No. 9, p. 128.

Figure 7. Banco de Puerto de Rico: Income, Losses and Profits, 1899-1912 (Thousands US dollars)

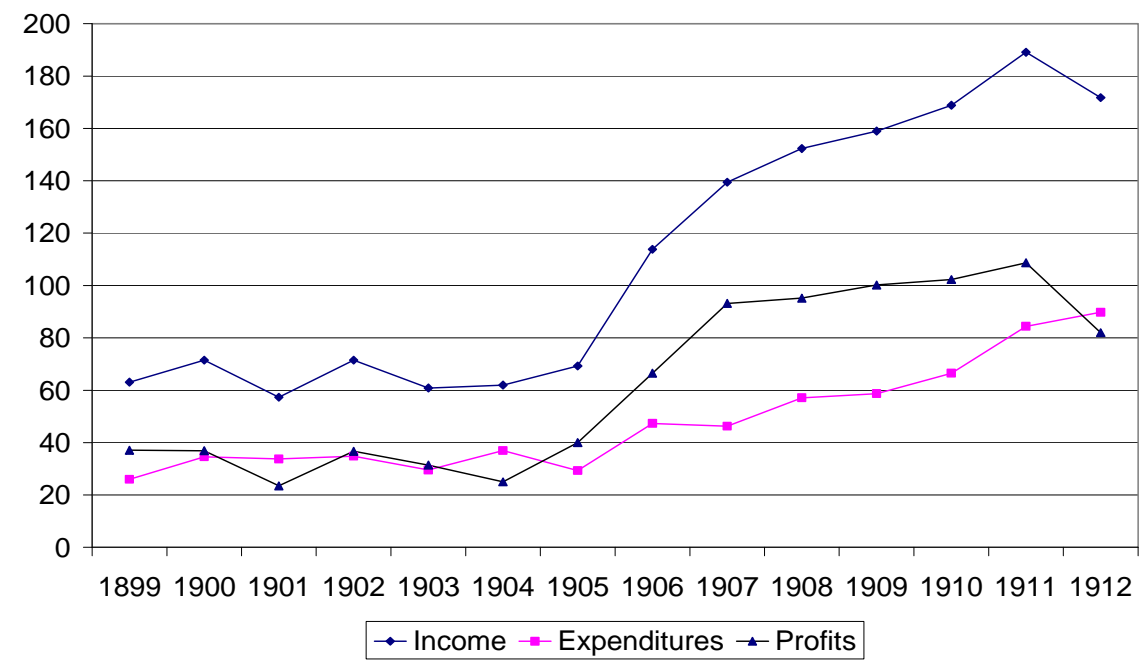

Sources: Appendix. 
Figure 8. Banco de Puerto de Rico: Return on Equity (ROE) and Solvency ratio, 1899-1912

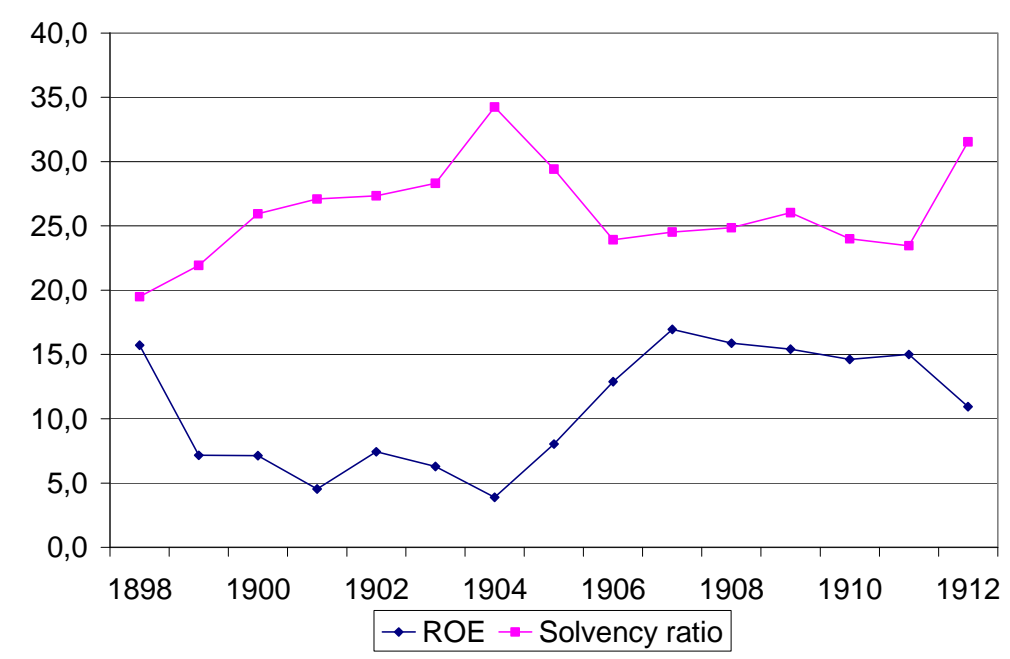

Sources: Appendix.

\section{Conclusions}

The aim of this article has been to trace the twenty-five year long history of the Banco Español de Puerto Rico, from its founding in 1888 to its liquidation in 1913. The Banco Español was the only bank of issue on the island until 1898, when the sovereignty of the colony passed to the United States of America. The institution lost its privilege when it was integrated into the banking system of the new metropolis, although it was able to maintain a prominent position in the financial structure of the island.

The creation of the Banco Español de Puerto Rico was belated compared with that of similar financial institutions in the Caribbean and was fraught with difficulties. Internal and external factors limited its growth during its early years: low capitalization, the dual currency of the colony, the economic crisis of 1897, and the low growth rate of the island's economy, weighed down by the fall in sugar and coffee prices. Nevertheless, the Banco Español de Puerto Rico contributed to increase the financial resources of the colony, broke the merchant bankers' oligopoly, forced a reduction in interest rates and its notes diversified the country's rudimentary payment system.

The change of sovereignty represented a harsh blow to the Bank. As an issuing institution, it did not fit easily into the banking system defined by the US National 
Banking Acts. Until the reform of its statutes in 1905, the Banco de Puerto Rico (as it was officially renamed) was paralyzed and its management practices and operations raised the suspicions of the island's Treasury officials, who disliked an institution that functioned beyond public control. The currency conversion and the economic and social problems of the first five years under US rule also hindered the development of the Bank, burdened by a portfolio of uncollectible debts. Once the accounts were restructured and circumstances took a turn for the better thanks to the recovery in sugar and coffee prices, the Banco de Puerto Rico experienced a significant expansion of its activities. Eventually in 1913, the franchise expired and its business was transferred to a new entity, the Banco Comercial de Puerto Rico.

The relationship between banking development and industrialization that was highlighted by Schumpeter, Gerschenkron and Cameron, and before them by Adam Smith, has been established empirically in various contributions81. In 1993 King and Levine published an influential paper formalizing the link between financial development and economic growth. Using from a broad sample of countries over three decades, and various economic and financial indexes, they found a high statistical and significant correlation between economic growth rates and levels of financial development. Another finding was that the degree of financial development was a good predictor of future long-term growth rates, of physical capital accumulation, and of technological progress and the resulting economic efficiency gains 82.

The Banco Español de Puerto Rico was founded in the hope of revitalizing the island's economy. However, the expectations held in their day by the Bank's founders -a bank of issue acting as the driving force behind economic development, capable of modernizing the monetary system, lowering interest rates and eradicating the financial control exercised merchant-bankers- were not fulfilled in their entirety. Although more research is needed, one could argued that the Banco de Puerto Rico contributed to the development of the Island's economy by increasing the supply of credit, reducing the cost of money, and by diversifying the means of payments. Nevertheless, its limited size, geographical spread and growth prevented its contribution from being greater.

\footnotetext{
${ }^{81}$ Raymond Goldsmith, Financial Structure and Development (New Haven, 1960), and Ross Levine and R. G. King, "Finance and growth: Schumpeter might be right", Quarterly Journal of Economics, 108, (1993), pp. 717-738, and Ross Levine, "Finance and Growth: Theory and Evidence", Handbook of Economic Growth (Amsterdam, 2005). Relevant historical contributions for Latin America, Gail Triner, Banking and Economic Development: Brazil, 1889-1939 (2000)

${ }^{82}$ Ross Levine and R. G. King, "Finance, entrepreneurship and growth: theory and evidence", Journal off Monetary Economics, 1993, 32, pp. 513-542.
} 
A history of success or failure? As a private company, the Banco Español de Puerto Rico was unquestionably a resounding success for its shareholders, as from their initial investment they obtained not insignificant yields, of some 21 per cent on average. Even in the worst years, the Bank continued to distribute dividends. By 1898, the Puerto Rican issuer had no major competitors. The colony's credit companies were small, and their financial muscle was as yet weak. None of them represented a challenge for the Banco Español. However, the high yields were only possible at the expense of lowering the level of solvency, which in some years fell below 10 per cent, suggesting that the Bank lacked an adequate capitalization. Under Spanish sovereignty, the Bank was managed in an unorthodox manner and without government control. With the transfer of sovereignty, the island's Treasury officials subjected the Bank to strict scrutiny, forced it to reduce its bills in circulation, to clean its portfolio of non-performing assets, and to provide for an adequate level of reserves. As a consequence profitability fell by half. However, after 1905 on winds of a favorable economic climate, the Bank again obtained good returns, a more than acceptable 14.5 per cent on average between 1906 and 1912.

The best that can be said of the institution is that despite the difficulties and obstacles of all kinds that the Bank found strewn across its path, it survived, and did so in an era in which bank mortality, both in the US and in Europe, was common and high. When its charter expired in 1913 its existence continued under the name of the Banco Comercial de Puerto Rico. In sum, rather than judging the trajectory of the Banco Español de Puerto Rico as a success or failure, what its history offers is a mixture of errors and achievements, of successes and setbacks. 


\section{APPENDIX}

TABLE A1. BANCO ESPAÑOL DE PUERTO RICO. MAIN ASSETS AND LIABILITIES, 1890-1899. In thousands of pesos. $\left(^{*}\right)$

\begin{tabular}{|c|c|c|c|c|c|c|c|c|}
\hline \multirow[t]{2}{*}{ ASSETS } & \multicolumn{2}{|c|}{$\begin{array}{c}\text { CASH RESERVES } \\
\text { (1) }\end{array}$} & \multicolumn{2}{|c|}{$\begin{array}{l}\text { LOANS AND } \\
\text { DISCOUNTS } \\
(2)\end{array}$} & \multicolumn{2}{|c|}{$\begin{array}{l}\text { CREDITS WITH } \\
\text { GUARANTEE } \\
(3)\end{array}$} & \multicolumn{2}{|c|}{$\begin{array}{c}\text { CREDITS } \\
\text { (4) }\end{array}$} \\
\hline & Mex. & Nat. & Mex. & $\mathrm{Nat}$ & Mex. & Nat. & Mex. & $\mathrm{Nat}$ \\
\hline 1890 & 223 & 329 & 225 & 142 & 267 & 104 & 95 & 48 \\
\hline 1891 & 439 & 215 & 408 & 73 & 701 & 86 & 55 & 32 \\
\hline 1892 & 1,447 & 124 & 564 & 21 & 879 & 74 & 98 & 75 \\
\hline 1893 & 1,417 & 522 & 617 & 26 & 738 & 42 & 237 & 50 \\
\hline \multirow[t]{2}{*}{1894} & 1,439 & 718 & 851 & 21 & 679 & 33 & 185 & 45 \\
\hline & \multicolumn{2}{|c|}{ Provincial } & \multicolumn{2}{|c|}{ Provincial } & \multicolumn{2}{|c|}{ Provincial } & \multicolumn{2}{|c|}{ Provincial } \\
\hline 1895 & \multicolumn{2}{|c|}{2,049} & \multicolumn{2}{|c|}{959} & \multicolumn{2}{|c|}{848} & \multirow{2}{*}{\multicolumn{2}{|c|}{$\frac{403}{728}$}} \\
\hline 1896 & \multicolumn{2}{|c|}{1,640} & \multicolumn{2}{|c|}{1,355} & \multicolumn{2}{|c|}{1,035} & & \\
\hline 1897 & & & \multirow{2}{*}{\multicolumn{2}{|c|}{$\frac{1,231}{710}$}} & \multicolumn{2}{|c|}{874} & \multicolumn{2}{|c|}{941} \\
\hline 1898 & \multicolumn{2}{|c|}{1,800} & & & & & \multicolumn{2}{|c|}{1,052} \\
\hline 1899 & \multicolumn{2}{|c|}{1,505} & \multicolumn{2}{|c|}{648} & \multicolumn{2}{|c|}{181} & \multicolumn{2}{|c|}{618} \\
\hline
\end{tabular}

\begin{tabular}{|c|c|c|c|c|c|c|c|c|c|}
\hline \multirow[t]{2}{*}{$\begin{array}{l}\text { LIABILI } \\
\text { TIES }\end{array}$} & \multicolumn{2}{|c|}{$\begin{aligned} \text { CAP. } & \text { RES. } \\
(5) & (6)\end{aligned}$} & \multicolumn{2}{|c|}{ BANKNOTES } & \multicolumn{2}{|c|}{$\begin{array}{c}\text { CURRENT } \\
\text { ACCOUNTS AND } \\
\text { DEPOSITS }\end{array}$} & \multicolumn{3}{|c|}{ ASSETS / LIABILITIES } \\
\hline & \multicolumn{2}{|c|}{ Nat. } & & $\begin{array}{l}\text { Nat. } \\
\text { In circulation }\end{array}$ & Mex. & Nat. & Mex. & Nat. & $\begin{array}{l}\text { Total } \\
\text { Mex. }\end{array}$ \\
\hline 1890 & 375 & - & 145 & (34) & 987 & 368 & 1,102 & 888 & 2,123 \\
\hline 1891 & 375 & 3 & 600 & (521) & 960 & 198 & 1,779 & 1,175 & 3,130 \\
\hline 1892 & 375 & 56 & 1,125 & $(1,055)$ & 1,339 & 144 & 3,046 & 1,700 & 5,120 \\
\hline 1893 & 375 & 56 & 1,125 & (779) & 1,893 & 25 & 3,067 & 1,676 & 5,145 \\
\hline 1894 & 375 & 56 & 1,125 & (603) & 2,161 & 21 & 3,265 & 1,647 & 5,340 \\
\hline & \multicolumn{2}{|c|}{ Provincial } & \multicolumn{2}{|c|}{ Provincial } & \multicolumn{2}{|c|}{ Provincial } & \multicolumn{3}{|c|}{ Provincial } \\
\hline 1895 & 375 & 56 & 1,185 & (879) & & & & 5,725 & \\
\hline 1896 & 510 & 77 & 1,759 & na & & & & 5,057 & \\
\hline 1897 & 750 & 113 & 2,248 & na & & & & 6,062 & \\
\hline 1898 & 750 & 113 & 1,995 & (993) & & & & 4,427 & \\
\hline 1899 & 750 & 113 & 1,594 & $1,151)$ & & & & 3,937 & \\
\hline
\end{tabular}

Notes:

$\left.{ }^{*}\right)$ From 1890 to 1894 figures are in Mexican or current money (Mex) and in National money (Nat).

After the currency exchange in 1895 all figures are expressed in Provincial money.

Col. 1: metallic (gold and silver) plus banknotes in the vault of the Bank.

Col. 4: includes the net balance of the Mayaguez branch, mortgages, and a small amount of Treasury bonds. In 1897 and 1898 it includes also holdings of municipal bonds.

Col. 5: paid-up capital.

Col.6: reserve funds.

Col. 7: Issue is the published figures in the official balance sheets. In parenthesis the actual banknotes in circulation.

Col. 9: to estimate total assets and liabilities in Mexican pesos, the rate of conversion used is taken from the "Income and Losses" account: 1890 (15\%), 1891 (15\%), 1892 (22\%), 1893 (24\%), 1894 (26\%), 1895 $(40 \%)$.

na: non available.

Sources: Banco Español de Puerto Rico, Memorias anuales, 1890-1899. 
TABLE A2. BANCO DE PUERTO RICO, 1890-1899. INCOME AND LOSSES ACCOUNT. In thousands of pesos.

$\begin{array}{cccc}\text { YEARS } & \text { INCOME } & \text { EXPENDITURES } & \text { NET BENEFIT } \\ 1890 & 71.0 & 26.3 & 44.7 \\ 1891 & 128.1 & 47.7 & 80.4 \\ 1892 & 178.1 & 52.7 & 125.4 \\ 1893 & 145.2 & 54.4 & 90.8 \\ 1894 & 179.0 & 81.0 & 98.0 \\ 1895 & 207.8 & 87.1 & 120.7 \\ 1896 & 240.1 & 88.7 & 151.4 \\ 1897 & 307.0 & 129.8 & 177.7 \\ 1898 & 236.4 & 100.8 & 135.6 \\ 1899 & 105.2 & 43.4 & 61.8\end{array}$

Sources: Banco Español de Puerto Rico, Memorias anuales, 1890-1899. 
TABLE A3. BANCO DE PUERTO RICO. MAIN ASSETS AND LIABILITIES, 1899-1912. In thousands of US dollars.

\begin{tabular}{|c|c|c|c|c|}
\hline ASSETS & $\begin{array}{c}\text { CASH } \\
\text { RESERVES } \\
(1)\end{array}$ & $\begin{array}{c}\text { LOANS AND } \\
\text { DISCOUNT } \\
(2)\end{array}$ & $\begin{array}{c}\text { CREDITS WITH } \\
\text { GUARANTEE } \\
(3)\end{array}$ & CREDITS \\
\hline $1899(*)$ & 903 & 389 & 109 & 371 \\
\hline 1900 & 773 & 442 & 93 & 374 \\
\hline 1901 & 734 & 297 & 52 & 482 \\
\hline 1902 & 706 & 417 & 45 & 424 \\
\hline 1903 & 593 & 448 & 21 & 431 \\
\hline 1904 & 692 & 525 & - & 249 \\
\hline 1905 & 578 & 526 & - & 226 \\
\hline 1906 & 575 & 912 & - & 50 \\
\hline 1907 & 639 & 1,399 & - & 50 \\
\hline 1908 & 588 & 1,528 & - & 50 \\
\hline 1909 & 524 & 1,596 & - & 50 \\
\hline 1910 & 589 & 1,887 & - & 50 \\
\hline 1911 & 590 & 2,144 & - & 50 \\
\hline 1912 & 474 & 1,258 & & \\
\hline
\end{tabular}

\begin{tabular}{|c|c|c|c|c|c|c|}
\hline $\begin{array}{c}\text { LIABILITI } \\
\text { ES }\end{array}$ & $\begin{array}{c}\text { CAPIT } \\
\text { (5) }\end{array}$ & $\begin{array}{l}\text { ESERV. } \\
\text { (6) }\end{array}$ & Issue & $\begin{array}{l}\text { JKNOTES } \\
\text { (7) } \\
\text { In circulation }\end{array}$ & $\begin{array}{c}\text { CURRENT } \\
\text { ACCOUNT } \\
\text { AND DEPOSITS } \\
(8)\end{array}$ & $\begin{array}{c}\text { TOTAL } \\
\text { ASSETS/LIABILITIES } \\
(9)\end{array}$ \\
\hline $1899(*)$ & 450 & 68 & 956 & (691) & 812 & 2,362 \\
\hline 1900 & 450 & 68 & 956 & $(407)$ & 437 & 1,997 \\
\hline 1901 & 450 & 68 & 843 & (293) & 395 & 1,912 \\
\hline 1902 & 450 & 44 & 798 & $(267)$ & 340 & 1,807 \\
\hline 1903 & 450 & 50 & 750 & (349) & 338 & 1,766 \\
\hline 1904 & 587 & 56 & 780 & (312) & 578 & 1,878 \\
\hline 1905 & 442 & 56 & 630 & $(395)$ & 502 & 1,693 \\
\hline 1906 & 450 & 66 & 640 & na & 901 & 2,158 \\
\hline 1907 & 450 & 100 & 650 & na & 867 & 2,244 \\
\hline 1908 & 450 & 150 & 635 & na & 1,003 & 2,415 \\
\hline 1909 & 450 & 200 & 600 & na & 1,070 & 2,497 \\
\hline 1910 & 450 & 250 & 500 & na & 1,543 & 2,917 \\
\hline 1911 & 450 & 275 & 500 & na & 1,690 & 3,092 \\
\hline 1912 & 450 & 300 & 375 & na & 1,091 & 2,379 \\
\hline
\end{tabular}

Notes:

(*) Figures for 1899 are taken from table A1 and converted into dollars at the official US\$0.66 rate.

Col. 5, Col. 6 and Col. 7, as in table 1

na: non available.

Sources: Banco de Puerto Rico, Memorias anuales, 1899-1913. For banknotes in circulation, Archivo General de Puerto Rico, box 1, "Issue of Bank Notes by the Banco Español de Puerto Rico. 
TABLE A4. BANCO DE PUERTO RICO. INCOME AND LOSSES ACCOUNT, 1899-1912. In thousands US dollars.

$\begin{array}{cccc}\text { YEARS } & \text { INCOME } & \text { EXPENDITURES } & \text { NET BENEFIT } \\ 1899\left(^{*}\right) & 63.1 & 26.0 & 37.1 \\ 1900 & 71.5 & 34.6 & 36.9 \\ 1901 & 57.3 & 33.8 & 23.5 \\ 1902 & 71.5 & 34.8 & 36.7 \\ 1903 & 60.9 & 29.5 & 31.4 \\ 1904 & 62.0 & 37.0 & 25.0 \\ 1905 & 69.3 & 29.3 & 40.0 \\ 1906 & 113.8 & 47.3 & 66.5 \\ 1907 & 139.5 & 46.3 & 93.2 \\ 1908 & 152.3 & 57.1 & 95.2 \\ 1909 & 159.0 & 58.7 & 100.2 \\ 1910 & 168.9 & 66.5 & 102.3 \\ 1911 & 189.1 & 84.4 & 108.7 \\ 1912 & 171.8 & 89.8 & 82.0\end{array}$

Notes:

$(*)$ Figures for 1899 are taken from table A1 and converted into dollars at the official US $\$ 0.66$ rate.

Sources: Banco de Puerto Rico, Memorias anuales, 1899-1913. 
TABLE A5. BANCO ESPAÑOL DE DE PUERTO RICO. RETURN ON EQUITY (ROE) AND SOLVENCY, 1890-1912. Percentages.

$\begin{array}{ccc} & \text { RETURN ON } & \text { SOLVENCY } \\ \text { YEARS } & \text { EQUITY ROE } & 17.7 \\ 1890 & 11.9 & 12.1 \\ 1891 & 21.1 & 8.4 \\ 1892 & 29.0 & 8.4 \\ 1893 & 21.1 & 8.1 \\ 1894 & 22.7 & 7.5 \\ 1895 & 28.0 & 11.6 \\ 1896 & 25.8 & 14.2 \\ 1897 & 20.6 & 19.5 \\ 1898 & 15.7 & 21.9 \\ 1899 & 7.2 & 25.9 \\ 1900 & 7.1 & 27.1 \\ 1901 & 4.5 & 27.3 \\ 1902 & 7.4 & 28.3 \\ 1903 & 6.3 & 34.2 \\ 1904 & 3.9 & 29.4 \\ 1905 & 8.0 & 23.9 \\ 1906 & 12.9 & 24.5 \\ 1907 & 16.9 & 24.8 \\ 1908 & 15.9 & 26.0 \\ 1909 & 15.4 & 24.0 \\ 1910 & 14.6 & 23.4 \\ 1911 & 15.0 & 31.5 \\ 1912 & 10.9 & \end{array}$

Notes:

ROE: ratio of net benefits to paid-up capital plus reserves.

Solvency ratio: capital plus reserves to total assets.

Sources: Banco Español de Puerto Rico, Memorias anuales, 1890-1899. 


\section{References}

Archivo General de Puerto Rico. Departamento de Hacienda. Serie Bancos y Tesorería. Archivo Histórico Nacional (Madrid). Ultramar, 321, 328, 332.

Acosta y Calvo, José Julián. 1887. El canje de la moneda de plata mejicana en Puerto Rico. Puerto Rico:_Establecimiento tipográfico de Meltz.

Allen, Charles H. 1901. First annual report of Charles H. Allen, Governor of Porto Rico covering the period_May 1, 1900 to May 1901.Washington, D.C.: Government Printing Office.

Anes Álvarez, Rafael. 1974. "El Banco de España (1874-1914): un banco nacional”, in Rafael Anes González, et. al. La banca española en la Restauración. I. Política y finanzas. Madrid: Banco de España, Pp. 172-215.

Asenjo y Arteaga, Federico. 1862. El comercio de la Isla y la influencia que en él ha de ejercer el Banco Español de Puerto Rico. Puerto Rico: Imprenta Militar.

Baldiority de Castro, Román. 1871. Bases para la fundación de un banco de emisión y descuento. Puerto Rico: Imprenta de Acosta.

Banco Español de Puerto Rico. 1888. Estatutos del Banco Español de Puerto Rico aprobados por real decreto de 5 de mayo de 1888 que acordó su creación. Puerto Rico: Tip. del "Boletín mercantil".

Banco Español de Puerto Rico. 1890-1913. Memoria leídas en la Junta General de accionistas.

Baralt, Guillermo A. 1993. Tradición de futuro: el primer siglo del Banco Popular de Puerto Rico, 1893-1993. San Juan: Banco Popular de Puerto Rico.

Baster, Albert S. J. 1929. Imperial Banks. London: Arno Press.

Beekman, Winthrop. 1906. Sixth Annual Report of the Governor of Porto Rico. Washington, D.C.: Government Printing Office.

Benítez Licuanan, Virginia. 1985. Money in the Bank. The story of money and banking in the Philippines. Manila: PCI Bank Human Resources Development Foundation.

Berbusse, Edward J. 1966. The United States in Puerto Rico, 1898-1900. Chapel Hill: University of North Carolina Press.

Bergard, Laird W. 1983. Coffee and growth of agrarian capitalism in nineteenth century Puerto Rico. Princeton: Princeton University Press.

Boletín Mercantil de Puerto Rico, 1890-1899. San Juan, P.R.

Brau, Salvador. 1904. Historia de Puerto Rico. Nueva York: D. Appleton y Compañía.

Cabrera, Gilberto. 1980. Historia económica del comercio y de la industria de Puerto Rico. Hato Rey, P.R.: Fundación Socio Económica de Puerto Rico.

Cameron, Rondo. 1967. Banking in the early stages of industrialization. New York, Oxford University Press.

Carroll, Henry K. 1899. Report on the island of Porto Rico: its population, civil government, commerce, industries, productions, roads, tariff, and currency, with recommendations. Washington, D.C.: Government Printing Office.

Castellano y Villarroya, Tomás. 1896. El canje de la moneda en Puerto Rico. Madrid: Hijos de J. A. García.

Chinea, Jorge L. 2010. "Confronting the crisis of the slave-based plantation system in Puerto Rico: bureaucratic proposal for the agricultural modernization, diversification and free labour, c. 1846-1852", Journal of Latin American Studies 42: 121-154.

Clark, Victor S. 1930. Porto Rico and its problems. Washington D.C.: Brookings Institution. 
Cochran, Thomas C. 1959. The Puerto Rican businessman: a study in cultural change. Philadelphia: University of Pennsylvania Press.

Colayco, Maria Teresa. 1985. A tradition of leadership: Bank of the Philippine Islands. Manila: Bank of the Philippine Islands.

Coll y Toste, Cayetano. 1899. Reseña del estado económico e industrial de la isla de Puerto Rico al tomar posesión de ella los Estados Unidos. Puerto Rico: Imprenta de La Correspondencia.

------ 1914-1927. Boletín histórico de Puerto Rico. San Juan: Tipografía Cantero Fernández y Co., 14 vols.

Colton, George R. 1910. Tenth Annual Report of the Governor of Porto Rico. Washington, D.C.: Government Printing Office.

------ 1911. Eleventh Annual Report of the Governor of Porto Rico. Washington, D.C.: Government Printing Office.

----- 1912. Twelfth Annual Report of the Governor of Porto Rico. Washington, D.C.: Government Printing Office.

Comín, Francisco, Ángel Pascual and Inés Roldán de Montaud. 2010. Las cajas de ahorros de las provincias de Ultramar, 1840-1898: Cuba y Puerto Rico. Madrid: Fundación de las Cajas de Ahorros.

Conant, Charles A. 1969. A History of modern banks of issue. New York: A.M. Kelley.

Cruz Monclova, Lidio. 1952-1964. Historia de Puerto Rico. Río Piedras: Editorial Universitaria, Universidad de Puerto Rico.

Davis, George W. 1899. Report of Brigadier-General George W. Davis on the Civil Government of Puerto Rico. Industrial and Economic Conditions. Washington, D.C.: Governmente Printing Office.

Denizet, Pierre. 1899. Les banques coloniales. Paris: A. Pedone Editeur.

Di Venuti, Biagio. 1950, Money and banking in Puerto Rico. Río Piedras: University of Puerto Rico Press.

Dietz, James L. 1986. Economic history of Puerto Rico. Princeton: Princeton University Press.

Dinwiddie, William. 1899. Puerto Rico: its conditions and possibilities. New York: Harper \& Bros.

El canje de la moneda en Puerto Rico. La opinión del Banco Español de esta Isla. 1898. Puerto Rico: Tip. Al vapor de "La Correspondencia".

Ely, Roland T. 1963. Cuando reinaba su majestad el azúcar. Estudio históricosociológico de una tragedia latinoamericana: el monocultivo en Cuba. Buenos Aires: Editorial Sudamericana.

Fernández Aponte, Irene. 1992. El cambio de soberanía en Puerto Rico. Madrid: Mapfre.

Fernández, Susan J. 2002. Encumbered Cuba: capital markets and revolt, 1878-1895. Gainesville: University Press of Florida.

Friedlaender, Heinrich. 1978. Historia económica de Cuba. La Habana: Editorial de Ciencias Sociales.

Friedman, Milton and Anna Schwartz. 1971. A Monetary history of the United States, 1867-1960. Princeton: Princeton University Press.

Gaceta de Madrid. Madrid.

García Álvarez, Alejandro. 1998, "Metamorfosis de una institución financiera: el Banco Español de la Isla de Cuba", Tiempos de América 2: 117-135.

García López, José Ramón. 1996. "Los comerciantes banqueros en el sistema bancario cubano, 1880-1910", in Naranjo, Consuelo, Miguel A. Puig Samper and Luis 
Miguel García Mora (eds.): La nación soñada: Cuba, Puerto Rico y Filipinas ante el 98, Aranjuez: Doce Calles, Pp. 267-292.

Gayer, Arthur D. Paul T. Homan and Earle K. Jones. 1938. The sugar economy of Puerto Rico. New York: Columbia University Press.

Gerschenkron, Alexander. 1962. Economic development in historical perspective. Cambridge Mass.: Harvard University Press.

Goldsmith, Raymond. 1969. Financial structure and development. New Haven: Yale University Press.

Grossman, Richard S. 2010. Unsettled account: the evolution of banking in the industrialized world since 1800. Princeton: Princeton University Press.

Informe relativo al Banco Español de Puerto Rico, luego Banco de Puerto Rico. 1925. San Juan: Puerto Rico,

Cantero, Fernández and Co. Inc.

Hunt, William H. 1902. Second Annual Report by William H. Hunt, Governor of Porto Rico. Washington, D.C.: Government Printing Office.

Jesús Toro, Rafael de. 1982. Historia económica de Puerto Rico. Cincinnati: SouthWestern Pub. Co.

Le Cheminant, Keith. 1931. Colonial and foreign banking systems. London: George Routhledge and Sons.

Le Riverend, Julio. 1974. Historia económica de Cuba. La Habana: Instituto Cubano del Libro.

Levine, Ross. 2005. "Finance and Growth: theory and evidence", in Philippe Aghion and Steven N. Durlauf (eds.), Handbook of Economic Growth. Amsterdam: Elsevier.

Levine, Ross and Robert G. King. 1993. "Finance and growth: Schumpeter might be right", Quarterly Journal of Economics 108 (3): 717-737.

1993. "Finance, entrepreneurship and growth: theory and evidence", Journal of Monetary Economics 32: 513-542.

Marichal, Carlos and Matilde Souto Mantecón. 1994. "Silver and situados: New Spain and the financing of the Spanish Empire in the Caribbean in the eighteenth Century", The Hispanic American Historical Review 74 (4): 587-613.

Marrero, Leví. 1985. Cuba. Economía y Sociedad. Barcelona: Playor, 15. vols.

Morales Carrión, Arturo et. al. 1983. Puerto Rico. A political and cultural history. New York: W.W. Norton; Nashville, American Association for State and Local History.

Moreno Fraginals, Manuel.1978. El ingenio: complejo económico social cubano del azúcar. La Habana: Editorial de Ciencias Sociales.

Moreno Fraginals, Manuel and José A. Pulido (undated), Cuba a través de su moneda. La Habana: Banco Nacional de Cuba.

Perloff, Harvey. 1950. Puerto Rico's Economic Future: a study in planned development. Chicago: University of Chicago Press.

Picó, Fernando. 1987. 1898: La guerra después de la guerra. Río Piedras, P.R.: Ediciones Huracán.

Piqueras, José A. 2006. "El periodo interventor y la dolarización de Cuba", in Martín Rodríguez y Alharilla (ed.), Cuba de colonia a república. Madrid: Biblioteca Nueva.

Porter, Robert P. 1899. Report on the currency question of Porto Rico by Robert P. Porter, special commissioner for the United States to Cuba and Porto Rico. Washington, D.C.: Government Printing Office. 
Post, Regis. H. 1907. Seventh Annual Report of the Governor of Porto Rico, Regis H. Post (July 1, 1906 to June 30, 1907). Washington, D.C.: Government Printing Office, 1907.

Pulido, José A. 1980. El Banco Español de la Habana. La Habana: Museo Numismático, Banco Nacional de Cuba.

Quintero-Rivera, Ángel G. 1974. "Background to the emergence of imperialist capitalism in Puerto Rico", in Adalberto López and Jaime F. Petras (eds.), Puerto Rico and Puerto Ricans. Studies in history and society. New York, John Wiley \& Sons. Pp. 89-117.

Rodríguez San Pedro, Joaquín. 1865-1869. Legislación ultramarina concordada y anotada. Madrid: Imprenta de Viota, Cubas y Vicente, 16 vols.

Roldan de Montaud, Inés. 2004. La banca de emisión en Cuba (1856-1898). Madrid: Banco de España, Estudios de Historia Económica, no. 44.

------ 2008. "Las Haciendas públicas de Cuba y Puerto Rico desde el grito de la independencia hasta el final de la colonia", in Inés Roldán de Montaud (ed.), Las haciendas públicas en el Caribe hispano durante el siglo XIX. Madrid: Consejo Superior de Investigaciones Científicas.

Rosenberg, Emily S. 1985. "Foundations of the United Sates International Financial Power: Gold Standard Diplomacy, 1900-1905”, Business History Review 59 (2): 169-202.

Sabio Alcutén, Alberto. 1999. "Un rasgo de la política monetaria en tiempo de guerra: el canje de moneda en Cuba y Puerto Rico, 1895-1898”, Tiempos de América 34: 3-18.

Sánchez Tarniella, Andrés. 1975, La economía de Puerto Rico. Puerto Rico: Ediciones Bayoán.

Sanromá, Joaquín María. 1873. Puerto-Rico y su hacienda. Madrid: Impr. de Fortanet.

Santamaría García, Antonio. 2007. "Crecimiento económico y renta colonial en Puerto Rico", in Inés Roldán de Montaud (ed.), Las haciendas públicas en el Caribe hispano durante el siglo XIX. Madrid: Consejo Superior de Investigaciones Científicas, Pp. 211-243.

Santiago de Curet, Annie. 1989, Crédito, moneda y bancos en Puerto Rico durante el siglo XIX. Río Piedras, P.R.: Editorial de la Universidad de Puerto Rico.

Sanz, Ángel. 1969. Reseña histórica de la banca en Puerto Rico. San Juan: Departamento de Instrucción Pública.

Scarano, Francisco A. 1984. Sugar and slavery in Puerto Rico: the plantation economy of Ponce, 1800-1850. Maddison, Wis.: University of Wisconsin Press.

Schumpeter, Joseph A. 1934. The theory of economic development. Cambridge: Harvard University Press.

Soest, Jaap van. 1979-1980. Trustee of the Netherland Antilles. A history of money, banking and the economy with special reference to the central Bank van de Netherlanse Antillen, 1828-6 february-1978. Zutphen: Walburg Press.

Szászdi, Adam. 1962. "Credit-Without Banking in early Nineteenth Century Puerto Rico", The Americas 19 (2): 149-171.

Tablada, Carlos and Galia Castelló. 2007. La historia de la banca en Cuba del siglo XIX al XX, Tomo I, La colonia. La Habana: Editorial de Ciencias Sociales.

Tedde, Pedro and Carlos Marichal (coords.). 1994. La formación de los bancos centrales en España y América Latina, siglos XIX y XX. Madrid: Banco de España, Servicio de Estudios.

Tortella, Gabriel. 1964. "Desarrollo de la industria azucarera y la guerra de Cuba", Moneda y Crédito 91: 131-163. 
Triner, Gail. 2000. Banking and Economic Development: Brazil, 1889-1939. New York: Palgrave.

Vázquez Queipo, Vicente. 1845. Informe fiscal sobre el fomento de la población blanca en la isla de Cuba y emancipación progresiva de la esclava; con una breve reseña de las reformas y modificaciones que para conseguirlo convendría establecer en la legislación y constitución coloniales. Madrid: Imprenta de J. Martín Alegría.

White, Trumbull. 1898. Our new possessions: a graphic account, descriptive and historical of the tropic islands of the sea which have fallen under our sway. Chicago, Imperial Publishing Company.

Zanetti, Oscar and Alejandro García. 1987. Caminos para el azúcar. La Habana: Editorial de Ciencias Sociales. 


\section{ENDNOTE:}

The Bank's balances and income and losses acounts included in the annual reports (Memorias anuales) are available to all readers interested in the original sources. Please write to pablo.martin@uah.es and the information will be sent by postal mail. 